\title{
ADEQUACY OF DOMESTIC AIRLINE SERVICE: THE COMMUNITY'S ROLE IN A CHANGING INDUSTRY*
}

To realize its full economic potential, a city must secure air service which keeps pace with community expansion. ${ }^{1}$ But the frequency and quality of available air transportation have deteriorated substantially in many of the nation's cities, ${ }^{2}$ as airlines have pursued the relatively large profits attending long-haul flights between major population centers. ${ }^{3}$ The trend toward curtailed operations in smaller communities is certain to become still more pro-

*In early 1959, the Yale Laze Journal received replies to a questionnaire sent to the chambers of commerce of seventy cities. The questionnaire was designed to elicit information concerning the economic characteristics of a community, the adequacy of its transportation, and local efforts to improve air service. Material obtained in this manner, together with covering letters from city officials, is hereinafter cited as QUESTTONNAIRE. The questionnaire and a list of the cities responding are set forth in the Appendix, pp. $1243-44$ infra.

1. Air commerce now occupies a leading position among the nation's transportation systems. Staff of Subcomm. No. 5, House Comm. on the Jubictary, 85tr Cong., 1st Sess., Report on AIRLInes 7 (Comm. Print 1957) [hereinafter cited as Report on AIRLINES]. In 1957, domestic intercity passenger miles of air travel exceeded total intercity rail transport (Pullman and coach combined), and comprised $40.5 \%$ of total passenger traffic by common carrier. 1958 CAA SxatisTICAL HaNDBOOK 70.

This Comment is exclusively concerned with domestic passenger service. For discussions of the air-freight industry, see Thomsas, Economic Regulatton of Scheduled AIr Transport 106-11 (1951) [hereinafter cited as Thomas]; Report on AirLines 2427, 163-79; Symposizm-Air Cargo, 15 LAw \& Contemp. Prob. 1 (1950). And for an analysis of international air transportation, see REPORT on AIRLINEs 33-43, 217-64; ThoMras ch. 4; Bebchick, The International Air Transport Association and the Civil Aeronautics Board, 25 J. AIR L. \& Coar. 8 (1958); Calkins, The Role of the Civil Aeronautics Board in the Grant of Operating Rights in Foreign Air Carriage, 22 J. AIR L. \& CoM. 253 (1955).

Nonscheduled carriers are not treated in this Comment, except that their relationship to the adequacy-of-service problem is analyzed in note 73 infra.

2. Of the seventy cities responding to the Journal Questionnaire, only twenty-four stated that airline service was adequate. No pattern was apparent, the dissatisfied cities being diverse in terms of geographic location, economic significance, and population.

3. See Frederick, Commiercial Air Transportation 407-08 (rev. ed. 1947) [hereinafter cited as FREDERICK] ; Seven istates Area Investigation, 1A Av. L. REP. \22226, at 14323-24 (CAB Dec. 8, 1958); Ogburn, The Soctal Effrets of Aviation 222-27 (1946).

According to an airport official who has devoted most of his professional life to the development of aviation:

In the area generally east of the Mississippi a mad scramble has been on for the past ten years among our main trunk lines to haul passengers in million dollar equipment, usually non, or one stop between the terminal points . . . at reduced fares, while the inland cities in between get very little consideration either by the [Civil Aeronautics Board] or the airlines for either commuter first class (full fare), coach or reduced fare service. Yet, the airlines yell for "new markets", and, 
nounced with the use of jet aircraft. ${ }^{4}$ Indeed, charges have already been made that some airlines deliberately furnish poor service at their less-lucrative stops, then request permission to suspend flights because traffic demand is inadequate. $^{5}$

The Civil Aeronautics Act of 1938 (Federal Aviation Act of 1958) ${ }^{6}$ authorized the Civil Aeronautics Board to allocate available carrier resources among the nation's cities through the certification of new routes ${ }^{7}$ and the enforcement of an "adequate service" standard. 8 At present, CAB decisions, subject only to judicial review, establish which cities are to receive air service and what operations are locally required. Since air transportation is but one facet of municipal development, the Board may lack the necessary perspective to determine a community's economic needs. ${ }^{9}$ Absent, however, a federal agency responsible for coordinating national transportation policy, ${ }^{10}$ or

however, their sales departments and schedulings have done little to promote the vast new markets which are flown over every day.

QUESTIONANAIRE.

Another airport manager reported that "the medium size community $(200,000$ to 500,000 population) has the most serious legitimate complaint. Particularly those communities located within 75 to 100 miles of a major airport ... . [for they do not] receive the service [they] can and will support." Ibid.

4. Cline, Airline Scheduling, Route Patterns and Sales, 23 J. Arr L. \& Coxr. 164 (1956) (jet-carrier route segments should be longer than 500 miles, preferably 750 to 1000 miles; in order to exploit the speed of jet aircraft, time spent at intermediate stations must be eliminated by overflying communities lying between large terminal points).

5. QUESTIONNAIRE. One eastern airport official claims that the underlying reason for poor trunkline service is the airlines' belief that no loss of revenue will result becauss passengers will use surface transportation or local air service to nearby major airports.

Trunk carriers are attempting to suspend service where presently authorized at medium size communities and they are using the old familiar method. Provide the poorest service possible, do not sell or merchandise what little is provided and when traffic declines, petition for suspension of service with the suggestion that a local service carrier be certificated in its place. They then make certain that restrictions be placed on the local carrier's certificate to insure that the passeriger is forced to go to the nearby major airport for airline service.

Ibid.

6. The Civil Aeronautics Act of 1938, ch. 601, 52 Stat. 973 [hereinafter referred to as "the act"; sections of the act will be cited as they appear in the Statutes at Large]. The Federal Aviation Act of 1958, 72 Stat. 731, 49 U.S.C.A. $\$ \$ 1301-1542$ (Supp. 1958), replaced the 1938 act on December 31, 1958, but made little or no substantive change in the statutory provisions discussed in this Comment. Since the material utilized in this Comment is geared entirely to the 1938 act, that act's section numbers will be cited. Whenever the Federal Aviation Act uses a different section number, this number will be indicated in parentheses; e.g., $\S 2$ of the act (now $\$ 102$ ).

7. See notes $19-38$ infra and accompanying text.

8. See notes 139-55 infra and accompanying text.

9. See statement by Wilfred Owan in National Resource Planning Boarr, Transportation and Natronal Policy 254-55 (1942).

10. The federal government once attempted to formulate a national transportation plan by establishing the Federal Coordinator of Transportation. The experiment did nut 
a body charged with formulating a national plan for urban development, ${ }^{11}$ the interaction of air service and city growth will doubtless remain exclusively within the original jurisdiction of the CAB. Hence, the Board will continue to be responsible for using its certification and "adequate service" powers to correct local inadequacies.

In discharging its functions, the Board may initiate proceedings against any carrier which provides a community with unsatisfactory service, or, within limits, may require an airline to undertake operations in a new locality. ${ }^{12}$ Aggressive community action is usually necessary to precipitate $C A B$ intervention, however. ${ }^{13}$ Alternatively, municipal officials may approach carriers directly and ask them to cooperate in efforts to obtain or improve servicethough airlines are often uninterested in any profit potential less than that available in the major market areas. ${ }^{14}$ The possible participants in a contest for airline service are therefore three-the $\mathrm{CAB}$, a carrier, and a city demanding increased air transportation.

\section{The Participants}

\section{The Civil Aeronautics Board}

Though vested with extensive regulatory authority, ${ }^{15}$ the $C A B$ has voluntarily confined its control over service deficiencies to certifying new carriers

prove successful, and the office was abolished in 1936. See MoDougar \& Haber, Property, Wealth, Land: Allocation, Planning and Development 1162 (1948). See generally Pegrum, The Special Problent of Inter-Agency Competition in Transport, 24 I.C.C. PRAC. J. 307 (1956).

11. The federal government's only effort to propound an urban development policy is contained in Nattonal Resources Conim., Our Cities: Their Role in the National Economy (1937). The National Resources Committee was abolished in 1944.

12. Section $1002(\mathrm{~b})$ of the act authorized the Board to investigate carrier compliance with the act's provisions; $\$ 1002(\mathrm{c})$ authorized the Board to enter compliance orders against dilatory carriers.

Under $\S 401(\mathrm{~h})$ (now $\S 401(\mathrm{~g})$ ), the Board on its own initiative may modify or alter a carrier's certificate so as to provide service to a hitherto unscheduled point. See notes 103-05 infra and accompanying text.

13. On its own initiative, the Board has undertaken only one investigation of carrier compliance with the adequacy requirement. See Investigation of Coach-Type Service in Certain New York Markets, No. 9973, CAB, 1959, discussed note 124 infra. The initial decision of the hearing examiner is pending.

14. See Seven States Area Investigation, 1A Av. L. REP. I 22226 (CABB Dec. 8, 1958), discussed notes 116-19 infra and accompanying text; Service to Ely, Nevada, Av. L. KEP. (1954-57 CAB Cas.) đ 21812 (1955), discussed notes 109-15 infra and accompanying text.

15. The Board issues the certificates of public convenience and necessity which are prerequisites to engaging in air transportation; grants the necessary permits to foreign air carriers; makes modifications, alterations, suspensions or revocations of such certificates and permits; establishes rates and tariffs; supervises the transportation of mail; requires elahorate reporting and accounting procedures by air carriers; controls mergers between air carriers, other mergers affecting air commerce, and interlocking directorates; 
and passing on proposed extensions to already existent routes. ${ }^{16}$ Under the Civil Aeronautics Act's "grandfather clause," certificates were automatically issued airlines for their routes in operation at the time the statute was enacted. ${ }^{17}$ In every other case, a route application is not approved unless it meets certain statutory prerequisites. ${ }^{18}$

When processing applications for certification, the CAB applies a series of tests derived from the broad policy statements in section 2 (now section 102) of the act, ${ }^{19}$ and from the requirement in section 401(d) (1) that transportation be for the "public convenience and necessity."20 Proposed service must

and supervises business practices and methods of competition within the industry. REPORT oN AIRLINES 48-53. On the regulatory authority of the CAB, see generally THomss ch. 3; Pufrer, Am Transportation 256-609 (1941) [hereinafter cited as Puffer]. On supplementary government controls over aviation, see PUFrer 610-37; REport on AIRLINES $60-67$. On the residual regulatory authority of the states over air commerce, see 54 MICH. I. REV. 998 (1956); 7 Sw. I.J. 293 (1953).

16. Under $\S \S 1002(\mathrm{~b})$ and $1002(\mathrm{c})$, the $\mathrm{CAB}$ has power to investigate compliance with the provisions of the act and to enter appropriate orders. But the Board has never issued a compliance order on account of inadequate service, though pending cases may result in such action for the first time. See notes 125-33, 155 infra and accompanying text. But see Continental Air Lines, Inc., Additional Air Service in Texas, 4 C.A.B. 215, 239 (1943) (if inadequate existent service proved, $C A B$ would issue compliance orders under $\$ 404$ (a) ("adequate service") rather than authorize new-carrier service) (dictum).

17. Section 401 (e) of the act. This section was repealed by the Federal Aviation Act of 1958, 72 Stat. 731, 49 U.S.C.A. \& 1301. (Supp. 1958), as now superfluous. See Puffer 110-38; Thomas 54-66, 56 n.41 (citing cases involving the issuance of "grandfather" certificates); Rhyne, The Civil Aeronantics Act of 1938 and Grandfather Certificates, 12 ATR L. REv. 245 (1941).

The "grandfather" clause required automatic certification "unless the service rendered by [the] . . applicant . . . was inadequate and inefficient. . ." \$ 401 (e) (1). Leading cases discussing the adequacy requirements under the provision include: Panama Airways, Inc., 2 C.A.B. 124, 129-30 (1940); Marquette Airlines, Inc., 1 C.A.A. 301, 307 (1939) ; Airline Feeder System, 1 C.A.A. 167, 169 (1939).

For a discussion of the "little grandfather clause" enacted in 1955, see note 70 infra.

18. Section 401 of the act. For an analysis of the process for issuing new certificates, see Pufrer 138-57. In certain instances, a carrier may be permitted to operate without a certificate under the exemption provisions of the act, $\$ \$ 1(2)$ (now $\$ 101(3)$ ) and 416 (b). See note 73 infra. The Board may also issue temporary certificates for a limited period of time under $\$ 401$ (d) (2). See Seven States Area Investigation, 1A Av. L. REP. II 22226, at 14297 (CAB Dec. 8, 1958) (temporary certificate given so Board will have opportunity to appraise competitive effect of service); Los Angeles Airways Renewal Case, 1A Av. L. Rep. ๆ 22190 (CAB July 28, 1958) (experimental nature of operations warrants more direct method of control such as that provided by temporary certificate).

19. Under $\$ 2$ (now $\$ 102$ ), the Board is to consider the following as "being in the public interest" and in accord with the "public convenience and necessity": the encouragement and development of an air transportation system; the needs of the public, the Post Office and the national defense; fostering sound economic conditions in the industry; the promotion of adequate, economical and efficient service; competition to the extent necessary to ensure the sound development of the industry; and the promotion of air safety.

20. The leading case articulating the factors constituting public convenience and necessity under $\S 401$ (d) (1) is Northwest Airlines, Inc., 1 C.A.A. 573 (1940). There, 
correspond to a public need ;1 $^{21}$ and every carrier must be "fit, willing and able to perform."22 More precise standards are also invoked in accordance with the nature of the contemplated operations. ${ }^{23}$ If an applicant seeks to become the first carrier over a given route, sufficient evidence of traffic potential must be adduced to warrant the route's authorization. ${ }^{24}$ If transportation is already being provided along the route sought, there are additional determinants: Can existing carriers meet the traffic demand satisfactorily ${ }^{25}$ If so,

the Board stated that the primary considerations are whether the new service will serve a useful public purpose responsive to the public need; whether this purpose can and will be adequately served by the applicant without impairing the operations of existing carriers contrary to the public interest; and whether the cost of the proposed service to the Government will be outweighed by the benefit which will accrue to the public. See also Eastern Air Lines, Inc.-Memphis-Greenville Operations, 4 C.A.B. 429 (1943) (Board must consider the relationship that a new route would bear to a nationally adequate and economically sound air transportation system, the needs of the particular system, and the needs of the particular communities to be served).

21. United Airlines Transp. Corp., 1 C.A.A. 778, 780 (1940). See Tromas 73-79; National Airlines, 1 C.A.A. 612 (1940) (Board must ensure against the inauguration of service in excess of requirements of the area affected in order that an uneconomical burden will not be placed upon the development of air transportation and upon the Government). In determining the need for service, the Board considers, among other things, population, commercial importance, economic characteristics, rail service, distance to be traveled in order to obtain air transportation, and comparative air service in cities of similar location, population, and economic importance. See United Airlines Transp. Corp., 2 C.A.B. 543 (1941). A community of interest and trade relationship among cities to be served along a proposed route must also be demonstrated. See, e.g., Northwest Airlines, Inc., 8 C.A.B. 487, 493-94 (1947); Northwest Airlines, Inc., 1 C.A.A. 573, 581. (1940).

22. Section 401(d) (1) of the act. See generally Thosas 67-68. This standard requires adequate capital, a qualified organization, technical knowledge of aircraft operation, familiarity with problems involved in common carrier transportation, and capability to operate efficiently and economically. Additional Service to Latin America, 6 C.A.B. 857, 899-900 (1946). Moreover, the applicant must have a service plan made by competent personnel, see Braniff Airways, Inc. v. OAB, 147 F.2d 152 (D.C. Cir. 1945), and must be willing to comply with the provisions of the act, New York-Florida Case, Av. L. Rep. (1954-57 CAB Cas.) $\pi 21993$, at 14761 (1956). See also Pan American Airways, Inc., 1 C.A.A. 695, 711 (1940) (in ascertaining fitness and ability, the then primary determinants were competency and financial ability of the applicant carrier). For further discussion of the requirement that an applicant be "willing" to perform, see note 104 infra and accompanying text.

23. See Pan American Airways, Inc., 11 C.A.B. 852, 925 (1950).

24. Continental Airlines, Inc., 1 C.A.A. 598 (1940). In considering the need for service, the Board does not normally confine investigation to data relating only to the city limits of the community to be served, but examines instead the entire traffic-generating area which would be served through the same airport. Reopened Charleston-Columbus Case, 1A Av. L. Rep. đI 22153, at 14061-62 (CAB Jan. 16, 1958). See OgburN, The Social EFrects of Aviation 220-21. (1946) (suggesting a twenty-five mile radius test).

The first carrier to operate over a given route is said to provide "first-carrier service."

25. See United Airlines Transp. Corp., I C.A.A. 778, 780 (1940); National Airlines, Inc., 1 C.A.A. 612, 624 (1940). See also New York-Florida Case, Av. L. REp. (1954-57 CAB Cas.) II 21993, at 14755 (1956) (additional carrier authorized because "the present short- 
can the applicant introduce other reasons (such as the inability of present carriers to develop the route seasonably) sufficient to justify certification ? $^{20}$

Even if existing lines could serve an expanding market effectively, the CAB might still conclude that the sound development of the air transport system requires another carrier in order to promote competition. ${ }^{27}$ Before creating or increasing competitive service, the Board makes certain that the revised market structure will produce a more effective pattern of air service without unnecessarily duplicating transport facilities. ${ }^{28}$ A more important economic consideration is the extent to which increased competition will fragmentize total market traffic among several airlines. ${ }^{29}$ On the one hand, if the carriers presently serving the area are not financially self-sufficient, the sudden interjection of a new competitor might necessitate an increase in their level of subsidy. ${ }^{30}$ On the other, if the applicant cannot profitably undertake the proposed route extension, the cost to him may also have to be absorbed (totally or partially) by subsidization. ${ }^{31}$ Consequently, authorization hinges on

comings in service have been shown to exist over a substantial period of time, and the existing carriers have not demonstrated their ability to overcome them").

26. See Additional Service to Latin America, 6 C.A.B. 857, 888 (1946) (services of additional carrier warranted because serving airlines would not fully develop traffic potential.) See also Great Lakes-Southeast Serv. Case, No. 2396, CAB, Sept. 30, 1958, pp. 1415 (overall development of transportation will be fostered by adding third carrier to the market even though services of existing carriers not legally inadequate).

27. See $\S 2$ (d) of the act (now $\S 102(d)$ ). Recently, the Board had made it clear that the benefits of competitive air service will not be withheld from the traveling public merely because existing carriers are rendering "adequate service." Tucson Airport Authority, Av. L. REP. (1954-57 CAB Cas.) If 21977, at 14702 (1956). See Maclay \& Burt, Entry of New Carriers Into Domestic Trunkline Air Transportation, 22 J. AIR L. \& Com. 131, 140 n.25 (1955) (citing cases). Cf. FCC v. R.A Communications, Inc., 346 U.S. 86, 94 (1953) (competition is relevant in weighing the public interest). See generally Keyes, Federal Control of Entry Into Air Transportation (1951).

The Board has denied the application of a carrier unable to provide the needed competitive service. Denver Service Case, Av. L. REP. (1954-57 CAB Cas.) II 21877, at 14439 (1955).

28. See Service in the Rocky Mountain States Area, 6 C.A.B. 695, 740 (1946) (duplication warranted only if incidental to other operations throughout the area); West Coast Case, 6 C.A.B. 961 (1946) (traffic potential not sufficient to justify authorization of route that would constitute substantial duplication of existing operations); New England Case, 7 C.A.B. 27 (1946) (duplication merited where competing carriers would provide essentially different services).

29. See Thomas 79-81 (also collecting cases). The diversionary impact on an existing carrier must seriously affect its financial position in order to justify withholding the authorization of needed competitive service. Great Lakes-Southeast Serv. Case, 1A Av. L. REp. If 22211, at 14222-23 (CAB Sept. 30, 1958); United Airlines Transp. Corp., 1 C.A.A. 778,780 (1940).

30. See Delta Air Corp., 2 C.A.B. 447, 493 (1941) (because traffic diversion occasioned by new carrier would result in needed increase of subsidy to established carrier, authorization denied).

31. See Northwest Airlines, Inc., 2 C.A.B. 627, 651 (1941) (services of additional carrier would require government financial support; application denied). 
whether, in terms of section 2's policy standards, the benefit accruing to the public warrants the cost to the Government. ${ }^{32}$

Once the Board concludes that the services of an additional carrier are justified, the problem of selecting an entrant from among two or more applicants may arise..$^{33}$ To gain approval, an airline must be physically equipped to provide effective competition for existing lines. ${ }^{34}$ Often, the CAB will also require that an applicant have a history of serving the relevant area, ${ }^{35}$ and that the proposed route extension be in harmony with the applicant's existing route structure. ${ }^{36} \mathrm{~A}$ grant of certificated authority must enhance rather than distort the competitive balance within the industry. ${ }^{37}$ And, if two or more lines are otherwise equally qualified, the Board will consider any differences in their prospective subsidy levels. ${ }^{38}$

32. See Northwest Airlines, Inc., 1 C.A.A. 573, 578-79 (1941). For general discussions, see Keyes, Federal Control of Entry into Atr Transportation ch. 8 (1951); Gill \& Bates, Airline Conrpetition 479-504 (1.949) [hereinafter cited as Gill \& Bates]; Thosras 95-100; Gellman, The Regulation of Competition in United States Domestic Air Transportation: A Judicial Survey and Analysis, 24 J. ArR L. \& Com. 410, 417-34 (1957).

Another important determinant in all authorization proceedings is whether the proposed route comports with the existent pattern of national air transportation. Pennsylvania Cent. Airlines, Inc., 1 C.A.A. 811, 816 (1940) ; see Pufrer 142.

33. See Thosras 81-84; Westwood, Choice of the Air Carrier for Neze Air Transport Routes, 16 Geo. Wash. L. Rev. 1, 159 (1947-1948).

Under the broad doctrine announced in Ashbacker Radio Corp. v. FCC, 326 U.S. 327 (1945) (a case concerned with the granting of radio licenses), the CAB must consider all mutually exclusive applications for route certificates before an award can be made. See Delta Air Lines, Inc. v. CA.B, 228 F.2d 17, 21 (D.C. Cir. 1955) (collecting cases at n.6); Note, 44 VA. L. Rev. 1147 (1958).

34. See Great Lakes-Southeast Serv. Case, 1A Av. L. Rep. If 22211, at 14225 (CAB Sept. 30, 1958) (Delta and Northwest favored over Capitol Airways because better able to use larger and more modern aircraft on authorized routes).

35. See, e.g., id. at 14225; Denver Serv. Case, Av. L. Rep. (1954-57 CAB Cas.) \21877, at 14434 (1955).

36. Mid-Continent Airlines, Inc., 6 C.A.B. 253, $262-63$ (1945). In the Great LakesSoutheast Serv. Case, 1A Av. L. REP. \ 22211, at 14223 (CAB Sept. 30, 1958), Northwest rather than National was authorized to serve the Chicago-Miami market because the route extension would be supported by traffic from cities beyond Chicago that Northwest was presently serving. National, on the other hand, would have had to depend solely on passengers enplaning and deplaning in Chicago, since its route structure did not extend any farther north or west.

37. Southwest-Northeast Serv. Case, Av. L. REP. (1954-57 CAB Cas.) If 21892, at 14491 (1955) ("It is vital . . to so develop the national air route structure as to tend to decrease rather than increase the gap between the relative size of the Big Four carriers and the smaller trunks."); see Great Lakes-Southeast Serv. Case, 1A Av. L. REP. \22211, at 14223, 14226 (CAB Sept. 30,1958) (Capital Airlines chosen to serve Buffalo-Florida markets because it would add strength to the carrier's system and improve its financial position); Taaffe, A Map Analysis of United States Airline Competition, $25 \mathrm{~J}$. AIR L. \& Coג. 121, 146 (1958). See 1956 CAB ANn. Rep. 1.

38. Geliman, supra note 32, at 424. See also Great Lakes-Southeast Serv. Case, supra nute 37 . Of course, decreased subsidy may not be compatible with the Board's policy of 


\section{Carrier Autonomy}

Though a carrier which has been authorized to operate over a designated route must comply with certain statutory obligations, it has almost complete dominion over the conduct of its operations. The act requires only that transportation be made available upon a reasonable request; that safe and adequate service, facilities and equipment be furnished; that carriers coordinate their through-flight scheduling; and that the airlines refrain from granting either an undue preference or unreasonable advantage to any particular person, port, locality or type of traffic. ${ }^{39}$ In addition, the Board has authority to impose other reasonable terms, conditions, or limitations if the public interest so requires. ${ }^{40}$ But nothing in a certificate may impair the carrier's right to "add to or change schedules, equipment, accommodations, and facilities." 11 Hence, an airline may institute changes in its schedule pattern upon giving simultaneous notice to the Board. ${ }^{42}$ While this practice can effectively relegate a car-

enhancing the industry's competitive structure, see note 37 supra, in which case the latter consideration prevails, Gellman, supra at 424.

39. Section 404(a) provides in part:

It shall be the duty of every air carrier to provide and furnish interstate and overseas air transportation, as authorized by its certificate, upon reasonable request therefor and to provide reasonable through service in such air transportation in connection with other air carriers; to provide safe and adequate service. ...

Section 404(b) provides:

No air carrier or foreign air carrier shall make, give, or cause any undue or unreasonable preference or advantage to any particular person, port, locality, or description of traffic in air transportation in any respect whatsoever or subject any particular person, port, locality, or description of traffic in air transportation to any unjust discrimination or any undue or unreasonable prejudice or disadvantage in any respect whatsoever.

40. Section $401(\mathrm{f})$ of the act (now $\S 401(\mathrm{e})$ ). In the Great Lake's-Southeast Serv. Case, 1A Av. L. Rep. If 22211, at 14223, 14229-30 (CAB Sept. 30, 1958), the CAB required Capital Airlines to make long-haul flights in order to prevent the carrier from concentrating service in a short-haul local market to the detriment of the established localservice carriers. Typically, restrictions of this type take the form of permitting service between a particular pair of points only on flights originating or terminating at a distant community. See also Tucson Airport Authority, Av. L. REP. (1954-57 CAB Cas.) \21977, at 14703-04 (1956) (prohibition of purely local traffic service); Seven States Area Investigation, 1A Av. L. REP. $\llbracket 22226$, at 14322-24 (CAB Dec. 8, 1958) (preclusion of nonstop service) ; cf. Large Irregular Air Carrier Investigation, No. 5132, CAB, Jan. 28, 1959, pp. 7-16 (restriction on number of flights flown per month by "supplemental" carriers). The certificate specifies the terminal and intermediate points between which the carrier is authorized to operate, $\S 401(\mathrm{f})$ (now $\S 401(\mathrm{e})$ ), and the type of service-mail, freight or passenger-to be rendered.

41. The fourth sentence of section $401(\mathrm{f}$ ) of the act (now $\S 401(\mathrm{e})$ ) provides that "no term, condition, or limitation of a certificate shall restrict the right of an air carrier to add to or change schedules, equipment, accommodations, and facilities for performing the authorized transportation and service as the development of the business and the demands of the public shall require."

42. CAB Econ. Reg., 14 C.F.R. § 231.5(c) (1956). If the schedule change affects the carriage of mail, the carrier must give ten days notice to the Postmaster General, and, 
rier's smaller stops to aerial obscurity, the statute allows an airline virtual autonomy over the scheduling of its flights.

In theory, the $\mathrm{CAB}$ has extensive statutory powers to rectify the service deficiencies of existing carriers; in practice, the Board exercises only nominal control. After investigation, the Board may issue an order to compel a dilatory carrier to comply with its "adequate service" obligation, but this prerogative has not been exercised. ${ }^{43}$ Moreover, an airline's failure to initiate flights after reasonable request by a community does not work an automatic forfeiture of its certificate; instead, the $\mathrm{CAB}$ may investigate at its discretion to determine whether revocation would be in the public interest. ${ }^{44}$ The optional feature of this provision has impaired its efficacy. ${ }^{45}$ The airlines' freedom in initiating service is evidenced by the fact that, although 590 cities appear on domestic route certificates, only 549 are presently receiving air transportation. ${ }^{46}$ Furthermore, an airline which is dissatisfied with operations at a particular community may obtain $\mathrm{CAB}$ permission to suspend service there-and often without having to subject its request to a formal hearing. ${ }^{47}$ Similarly, if a certifi-

unless he disapproves, may institute the change. See $\S 405$ (e) of the act (now $\S 405(b)$ ) and CAB Econ. Reg., 14 C.F.R. § 231.5(b) (1.956).

43. Sections $1002(b)$ and (c) of the act. The Board early recognized that it had statutory authority to compel the airlines to give "adequate service" to points authorized to receive service. United Air Lines Transp. Corp., 1 C.A.A. 723 (1940). But the Board has yet to issue an order compelling a carrier to comply with the $\S 404(a)$ "adequate service" standard. The Board did "informally" order a carrier to increase service in the Niagara Falls Airport Case, 18 C.A.B. 693, 694 (1954). The hearing examiner had held that the service being provided by American Airlines at Niagara Falls was inadequate. The Board, affirming, stated that if the carrier did not improve its schedule pattern, the city could raise the question of compelling additional service in a new proceeding under $\S 404$ of the act. In the first adequacy case under $\S 404$ (a), Fort Worth Investigation, 1A Av. L. REP. I 22205 (CAB Sept. 23, 1958), discussed notes 139-72 infra and accompanying text, the Board deemed existing service adequate and refused to order an increase in operations. Pending cases, however, may bring about a modification of Fort Worth. See notes 125-33, 155 infra and accompanying text.

44. "[I]f any service authorized by a certificate is not inaugurated ... the Authority may by order, entered after notice and hearing, direct that such certificate shall thereupon cease to be effective to the extent of such service." Section $401(\mathrm{~g})$ of the act (now $\S 401(f))$.

45. There have been but three cases in which a carrier's certificate was revoked because of a failure to inaugurate service. See Northern Cross, Inc., Certificate Nullification, 11 C.A.B. 673 (1950); Parks Investigation Case, 11 C.A.B. 779 (1950); Tri-State Aviation Corp., Revocation of Certificate, 4 C.A.B. 100 (1943).

46. $1958 \mathrm{CAA}$ Statistical HANDBOOK 62. This figure includes cities which are receiving service from some but not all locally authorized carriers.

47. While $\S 401(k)$ of the act (now $\S 401(j)$ ) requires the $C A B$ to hold a hearing prior to "abandonment," the CAB Econ. Reg., 14 C.F.R. $\S 205$ (1956), provides for a "temporary suspension" by board order alone. The distinction has become somewhat blurred. "Although from the standpoint of potential users of service the end result of abandonment, suspension, or revocation may be exactly the same, i.e., loss of service, these three are not necessarily the same. Abandonment and revocation both have the attribute 
cate-holder prefers to serve a city through a different airport, it may divert its flights thirty days after notifying the Board of the proposed shift, provided the $\mathrm{CAB}$ has not issued a restraining order. ${ }^{48}$ Hence, unless the $\mathrm{CAB}$ decides that the public interest will be harmed, a carrier may institute a changeover without formal approval. ${ }^{49}$ Also, if a carrier wishes to commence nonstop, long-haul service between two cities which are on its route but are not consecutively named in its certificate, it may do so upon notice to the Board. ${ }^{\text {fin }}$ In short, the act affords the certificated carriers substantial flexibility in providing air transportation, and allows managerial rather than administrative decisions to govern service operations. ${ }^{51}$

\section{The Industry}

Deeming a commercial air fleet vital to both the economy and national defense, Congress has guarded the airline industry's interests and guaranteed a reasonable profit to any prudently managed carrier serving a needed route. ${ }^{\text {.* }}$

of finality, while suspension permits possible return to the original status." All American Airways, Inc., Suspension Case, 10 C.A.B. 24, 27 (1949). (Emphasis added.) "Returns to the original status" are rare. Also, the CAB may suspend service on its own initiative under $\$ 401(h)$ of the act. See North Central Route Investigation Case, 14 C.A.B. 1027, $1050-52$ (1951). Scheduling freedom is further enhanced by allowing the carriers to suspend service without either application or order if they have never inaugurated regular service at a given point. CAB Econ. Reg., 14 C.F.R. \$205.6 (1956).

48. CAB Econ. Reg., 14 C.F.R. § 202.3 (1956).

49. See Service to Springfield, Mass., 11 C.A.B. 747 (1950) (airport transfer re* quired by public interest).

50. CAB Econ. Reg., 14 C.F.R. § 202.2 (1956). Nonstop service may be instituted upon the effective date of a schedule page filed with the Board if the carrier's certificate does not preclude such service. See note 40 supra. Also, nonstop service on flights carrying mail may not be inaugurated unless the Postmaster General approves. See note 42 supra.

51. The Board has stated that the purpose of preventing it from restricting schedule changes "is to help delineate the respective spheres of the carriers and the Board in order to assure to each certificated carrier the managerial freedom to conduct its operations within the scope of its authority at its own discretion or judgment without the impediment of regulatory restrictions in its certificate in the respects indicated." Large Irregular Air Carrier Investigation, No. 5132, OAB, Jan. 28, 1959, p. 8. The Board has required adherence to published schedules, however. In 1957, the CAB stipulated that domestic certificated carriers must complete at least $75 \%$ of all flights within fifteen minutes of the time shown in their schedules. 42 C.F.R. $\$ 234.4$ (Supp. 1959). Any failure to comply with this regulation during a three-month period is a violation of the holder's certificate unless noncompliance is justified by circumstances beyond the carrier's control. 1957 CAB ANn. Rep. 15. To date, no proceedings have occurred under this order.

52. In fixing and determining fair and reasonable rates of compensation under this section, the Authority ... shall take into consideration ... the need of each such carrier for compensation for the transportation of mail sufficient to insure the performance of such service, and, together with all other revenue of the air carrier, to enable such air carrier under honest, economical, and efficient management, to 
The growth of air commerce has been protectively nurtured, ${ }^{53}$ and the industry has long been proffered the teat of subsidy. Before World War II, federal encouragement was confined solely to the trunkline carriers providing passenger service between major commercial centers. ${ }^{54}$ Their dominance over the air market was maintained by the automatic-certification ("grandfather") clause of the Civil Aeronautics Act."5s After the war, the bulk of subsidy payments went to non-trunklines, while trunk carriers made tremendous advances toward their goal of economic self-sufficiency. ${ }^{56}$ Since 1957 , in fact, none of

maintain and continue the development of air transportation to the extent and of the character and quality required for the commerce of the United States, the Postal Service, and the national defense.

Section $406(\mathrm{~b})$ of the act. Subsidy payments guarantee the airlines that, so long as they are soundly managed, the United States will underwrite their business. See REPORT oN AIrLINEs 16 \& n.34. For general discussions, see Gifford, The Evolution of Air Irail Rate Making, 22 J. AIr L. \& Cox. 298 (1955); O'Connell, Air Mail Pay Under the Civil Aeronautics Act, 25 IND. L.J. 27 (1949); Comment, 55 CoLum. L. REv. 933 (1955).

53. The lure of controlled competition and chronic financial difficulties during the aviation industry's formative years led representatives of both the scheduled airlines and the industry's trade group, the Air Transport Association, to assume a prominent role in securing government controls. REPORT ON AIRLINEs 2, 13-14. See the testimony of Edgar S. Gorrell, Air Transport Association, Hearings on H.R. 5234, 74th Cong., 1st Sess. 66 (1937). The established subsidized carriers feared that a new firm would begin competition with used equipment and low costs, and that the ensuing rate wars would bring disaster or near-disaster. PUFFER 52. "A large part of the demand for regulation has come from the industry itself." Id. at 57. Prior to 1938, it was estimated that half of the $\$ 120$ million invested in the industry had been lost. Altschul, Economic Regulation of Air Transport, 12 J. AIR L. \& CoM. 163 (1941). See also Comment, 67 YALE L.J. 1024, 1033 (1958).

54. A trunkline carrier is one whose certificate authorizes it to provide regularly scheduled service of an express, long-haul character. 1955 CAB Aivis. REP. 25. There are, at present, twelve certificated domestic trunklines. 1958 CA'A Statistical HANDBooK 62.

55. Twenty-three domestic trunklines were originally granted certificates as "grandfather" carriers. A series of mergers, changes in corporate name, and one abandonment have succeeded in reducing the roster of "grandfathers" to twelve. In other words, all present trunklines, or their predecessors in interest, are "grandfather" carriers. REPORT on AirLines 18-19. The "Big Four"-American, TWA, Eastern and United-accounted for $72 \%$ of the total revenue passenger-miles flown by all certificated trunk carriers between September 1957 and September 1958. CAB, Monthly Report of Air Carriers Traffic Statistics, Sept. 1958, p. 54.

For a criticism of the CAB's policy of meeting domestic transportation requirements primarily by expanding the routes of "grandfather" carriers, see Maclay \& Burt, supra note 27.

56. Between 1947 and 1956, the total operating revenue of all carriers increased $228 \%$ and between 1949 and 1956 net income increased 369\%. 1957 CAB ANN. REP. 39. Total annual subsidy payments have decreased from $\$ 70$ million in 1951 to $\$ 42$ million in 1957 , the major portion of which was received by thirteen local-service carriers. Id. at 10 . For a recent summary of the industry's financial position and outlook, see Doty, Resurging Trunk Traffic Won't Be Cure-All, Aviation Week, March 9, 1959, p. 135. 
the twelve trunklines has needed direct subsidy, ${ }^{57}$ although at least one of these carriers may again require government assistance. ${ }^{58}$

Attempting to retain their hard-won financial independence, the trunklines have been consistently decreasing their short-hop ("puddle-jumping") flights. ${ }^{50}$ And, in orienting operations away from the smaller communities, they have been able to realize the higher profits produced by serving major market areas

57. Hess, The Grozering Pains of Jet Travel, The Reporter, Dec. 25, 1958, pp. 9, 13. See Seven States Area Investigation, 1A Av. L. REP. \22226, at 14323 (CAB Dec. 8, 1958) : "[T] he trunkline carriers have, in a real sense come of age, and . . are, for all practical purposes, no longer dependent upon Government subsidy." See also Smith, Govermment Policy Concerning Airline Subsidy, 25 J. AIr L. \& Com. 79 (1958).

58. 'See Northeast Airlines, Inc., 1A Av. L. REp. I 22242 (CAB Feb. 19, 1959).

59. This decrease is strikingly illustrated by the following chart. The chart correlates the statistics on annual domestic aircraft departures, 1958 CAA STATISTICAL HANDBook 100, with data on total annual domestic plane-miles flown, id. at 104; 1957 CAB ANN. REP. 43. These figures show that, as the number of flights increased, so did the average distance between stops; hence, a definite trend toward decreased short-haul air carriage is indicated.

\begin{tabular}{cccc}
\hline \hline & $(\mathrm{A})$ & $(\mathrm{B})$ & $(\mathrm{C}){ }^{*}$ \\
Year & Aircraft Departures & Plane Miles Flozm & Average Trip Letrgth \\
\hline 1949 & $2,023,702$ & $333,707,756$ & 165 miles \\
1951 & $2,319,143$ & $393,594,619$ & 170 \\
1953 & $2,612,767$ & $505,074,347$ & 193 \\
1955 & $2,901,758$ & $606,584,011$ & 209 \\
1957 & $3,318,282$ & $711,126,846$ & 232 \\
\hline
\end{tabular}

*Column (B) divided by column (A)

The following table, broken down in individual trunk-carrier operations, illustrates the trend between 1950 and 1953 toward increased long-haul carriage.

\begin{tabular}{lccc}
\hline Carrier & $\begin{array}{c}\text { Average Flight } \\
1950\end{array}$ & 1953 & $\begin{array}{c}\text { Increase } \\
\text { (Decrease) }\end{array}$ \\
\hline American & 259 & 309 & 50 \\
Braniff & 168 & 164 & $(4)$ \\
Capital & 136 & 151 & 15 \\
Continental & 128 & 146 & 18 \\
Delta & 215 & 184 & $(31)$ \\
Eastern & 183 & 212 & 29 \\
National & 180 & 228 & 48 \\
Northeast & 87 & 104 & 17 \\
Northwest & 258 & 300 & 42 \\
TWA & 274 & 348 & 74 \\
United & 262 & 305 & 43 \\
Western & 181. & 183 & 2 \\
\hline
\end{tabular}

Source: 1950-1951 WoRLD AirLINE ReCoRd; 1955 id.

In Phoenix, Arizona, for example, the percentage of flight stages (average nonstop trip length) to and from the city which were over 500 miles long increased from $4.4 \%$ in April, 1953 to $14.3 \%$ in April, 1957. James C. Buckley, Inc., Industrial \& Transportation 
on a nonstop basis. ${ }^{80}$ The trend is mirrored in their equipment purchases over the past decade. In 1949, 333 four-motor and 420 two-motor planes were being operated by the nation's domestic trunklines; ${ }^{61}$ in January 1959,853 four-motor and 405 two-motor aircraft were in use. ${ }^{62}$ Thus, as the two-motor fleet was kept nearly constant, ${ }^{63}$ the funds generated for acquiring new equipment were channeled primarily into purchasing long-haul, high-speed aircraft. ${ }^{04}$ Not surprisingly, the trunklines have become ill-equipped to service small cities. ${ }^{65}$

Consultants, Sky Harbor Municipal Airport, Phoenix, Arizona: Terminal Development Study-Review and Revision of Airport Master Plan (Oct. 10, 1958).

Another index of the shift in carrier and $C A B$ policy over the past eight years is the decrease in cities with authorized service. In 1950, the Board had approved service to S07 domestic cities; by 1958 this number had dropped to 590. 1958 CAA Statistical HANDBook 62. In 1950, carriers were serving 568 cities, in 1951 an all-time high of 593; but by 1958 only 549 were receiving air transportation. Ibid. Trunkline abandonment of the small communities was one of the factors leading to the authorization of local-service carriers in the Seven States Area Investigation, 1A Av. L. REP. $\{22226$ (CAB Dec. 8, 1958), discussed notes 115-18 infra and accompanying text.

60. See Maclay \& Burt, supra note 27 , at pp. $152-53$; note 3 supra and accompanying text.

61. See data listed under each carrier in 1950-51 WoRLd AIRLINe Recond; 1958 CAA Statistical HandBook 64. (The figures in text do not include aircraft used solely in air-freight transportation.)

62. FAA, United States Aircraft Engaged in Air Transportation. (Agency Statistical Report, Jan. 14, 1959). (The figures in text do not include aircraft used solely in air-freight transportation.)

63. Aircraft are kept serviceable for extended periods of time through the practice of constantly replacing their internal parts. See N.Y. Times, May 26, 1958, p. 29, col. 1 (spare parts keep aircraft "ageless"). Hence, the only reason for acquiring improved short-haul equipment would be obsolescence, and, until recently no substantial improvement in short-haul aircraft had occurred. See Adams, Future Local Airline Service Depends on State Support, 20 J. AIR L. \& Coxr. 403, 414 (1953); 1951 CAB ANN. REP. 2. Late last year, the Fairchild F-27, a turbo-prop aircraft particularly adapted to localservice air carriage, was put into operation. See Reed, $F-27 s$ Boost West Coast Revenue Miles, Aviation Week, March 9, 1959, p. 28. In January 1959, ten F-27s were being used by two local-service carriers. See FAA, United States AIRCRAFT ENGAged IN AIR Transportation (Agency Statistical Report, Jan. 14, 1959).

64. During 1956-57, only 12 additional two-motor planes were acquired by all certificated carriers; in contrast, the four-motor fleet was increased by 124 new craft. 1958 CAA Statistical HaNdBook 64. Braniff and Western report that they have disposed of all their two-motor DC-3's because smaller schedule points have been eliminated and system operations expanded. Seven States Area Investigation, 1A Av. L. REP. If 22226, at 14321 (CAB Dec. 8, 1958).

65. See U.S. Presinent's Air Coordinating Committee, Civir Air Policy 11 (1954) (modern aircraft necessitate long-range, high-load-factor operations).

Noting a recent decrease in service by all authorized trunklines, one community stated that, although the lines blamed lack of demand, "locally it is believed that equipment needs and scheduling were primary considerations." A number of other cities also attributed curtailed operations to equipment shortages. Questionnarre.

The use of larger aircraft permits an airline to reduce the number of its flights without reducing the number of available seats; hence, at a given community, departures may 
Even if, contrary to fact, the trunk carriers were disposed to acquire modern short-haul equipment, the technology and logistics of the jet age would preclude such purchases. ${ }^{66}$ Actively engaging in their own armament race, the trunklines are converting to jet aircraft whose most efficient cruising altitude of 35,000 feet ${ }^{67}$ makes the short hop infeasible. ${ }^{68}$ Not only will the cost of conversion absorb all available funds, but it will also necessitate expanding long-haul service while restricting short-range operations in order that the carriers may attract needed capital by means of maximized earnings. Thus, the trunklines may soon force token service upon all but the leading air markets. ${ }^{69}$

A countervailing development is found in the short-range flights which, with increasing frequency, local-service carriers provide communities unable to attract trunkline operations. ${ }^{70}$ Since 1950 , local-service (or, as it is some-

become less frequent and passengers may be forced to board at more inconvenient times. One city reported that the serving trunkline "has decreased service, as it has within the past few months disposed of the last of its $D C-3$ equipment. It is now providing service ... with fewer flights, although the number of seats has not been decreased." QuEstionNAIRE.

66. Over $\$ 1$ billion will probably be needed by the industry as a whole for the conversion to jet aircraft. Donahue \& Perry, Airline Financing and Operational Problcms, 23 J. AIR L. \& Cosr. 151 (1956). See also Hess, The Growing Pains of Jet Travel, The Reporter, Dec. 25, 1958, pp. 9-10. The airlines may experience great difficulty in raising the necessary funds. Forbes, Jan. 1, 1958, pp. 23-26. If so, the lines will be most unlikely to invest in short-haul equipment or service. See also Hector, Problems in Economic Regulation of Civil Aviation in the United States, 26 J. Arr I. \& CoM. 101 (1959) (discussion of the current re-equipment "crisis").

67. Hess, supra note 66 , at 10 .

68. See Cline, Airline Scheduling, Route Patterns and Sales, 23 J. AIR L. \& CoM. 164 (1956) ; see also Wall Street Journal, Aprii 14, 1959, p. \&, col. 4 (carriers will have difficulty maintaining high-load factors on jets unless merchandising methods improve).

69. See Doty, Resurging Trunk Traffic IVon't Be Cure-All, Aviation Week, March 9, 1959, p. 135. In the Northeastern States Area Investigation, No. 6436, CAB, 1959, wherein American Airlines is seeking permission to suspend service at Connecticut cities, one of the carrier's officers stated: "American's future equipment plans . . . will provide American with turbo-prop aircraft, the Lockheed Electra, with a capacity vastly in excess of the traffic which Bridgeport and New Haven could be expected to generate in the foreseeable future." Quoted in Brief of Bridgeport, New Haven, and New London to the CABB, p. 1.1.

One city remarks: "On the whole we have excellent trunkline service but worry about the effect of jets on the smaller intermediate cities between largc centers." QuEsTrowNAIRE (Emphasis added.).

70. The CAB first enunciated its policy of certificating a system of local-service carriers on an experimental basis in the Investigation of Local, Feeder and Pick-Up Air Serv., 6 C.A.B. 1 (1944). The first local-service certificate was granted in 1945. Continental Air Lines, Inc., Texas Air Service, 6 C.A.B. 289 (1945). Today, there are thirteen such carriers. 1958 CAA STATISTICAL HANDBook 62. In 1955, Congress enacted a little "grandfather clause." 69 Stat. 49, as amended, 49 U.S.C. $\$ 401$ (c) (Supp. V, 1958). This provision required the $O A B$ to make permanent all outstanding local-service certificates held by carriers in operation since January 1, 1953; the Board's power was to be 
times called, feeder-line) traffic has quadrupled. ${ }^{71}$ But its percentage of total industry traffic remains minimal. ${ }^{72}$ Some short-haul carriers which are attempting to become fully self-supporting have joined the pursuit of largemarket traffic, and the distinction between trunk and feeder lines is not always preserved. ${ }^{73}$

exercised on the same basis as had been employed in certifying "grandfather" trunk carriers. See note 17 supra.

The function of local-service carriers has been defined as providing flights "designed to connect with trunkline carriers for the onward passage of long-distance travelers originating at or destined to smaller communities." Young, Member of the Board, quoted in Thomas 100 n.194; see Texas-Oklahoma Case, 7 C.A.B. 481, 532 (1946) (concurring and dissenting opinion). See generally Seven States Area Investigation, 1A Av. L. ReP. II 22226, at 14321 (CAB Dec. 8, 1958); FREDERICK 195-222; Ray, The Feeder Airline Story, 16 J. ArR L. \& CoMr. 379 (1949); Zook, The Certification of Local and Feeder Air Carriers, 7 Sw. L.J. 185 (1953).

71. In 1950, local service carriers accounted for $188,749,000$ passenger miles. $C A B$, Bureau of Econoaitc Regulation, Accounting and Rates Division, Recurrent Report of Mileage and Traffic Data (1950). During the twelve month period ending Sept. 30, 1958, the corresponding figure was $786,436,000$ passenger miles. See CAB, Mionthly Report of Air Carrier Traffic Statistics 54 (Sept. 1958).

Subsidy requirements have not increased proportionally. In 1951, the local-service carriers received $\$ 17,410,000$ in subsidy; in 1958 , it was estimated that $\$ 26,871,000$ would be necessary. See CAB, Service Mail Pay and Subsidy for U.S. Certificated Air CarRIERS (1954).

72. Because of their typically short-haul operations, and the fact that they do not provide direct (one-plane) or nonstop service between major cities, the local service lines generate but a small proportion of total airline business. In 1958, local-service carriers accounted for only $3.2 \%$ of overall passenger miles flown by certificated carriers. CA.B, Monthly Report of Air Carrier Traffic Statistics 54 (Sept. 1958). See also Report on Airlines 24.

73. See Middle Atlantic Area Case, 10 C.A.B. 41, 45 (1949). Restrictions were placed on local-service carriers in the Seven States Area Investigation, No. 7454, CAB, Dec. 8, 1958, pp. 143-50, to prevent any further expansion into the long-haul service market. See CAB Policy Statement on Local Air Carriers, 2 Av. L. Rep. If 23123 (Sept. 25, 1951).

One eastern airport official states that the majority of local-service carriers have failed to develop local markets or to time flights so that they connect with trunklines at transfer points. Instead, he claims, the feeders seek to grow bigger, to "skim the cream" at larger terminals, and to become trunkline carriers. QuestronNaIRE.

The average flight-stage length of all the local service carriers was 85.2 miles in 1958, a 2.5 mile increase over the 1957 average. Aviation Week, March 9, 1959, p. 149.

Helicopter service may provide an alternative solution for the smaller communities, or at least for the air commuter. Currently, though, only three cities-New York, Chicago and Los Angeles-have certificated helicopter carriers. 1958 CAA Statistical HaNDBooK 62. See generally Sawyer, The Promise of Helicopter Transportation, 23 J. AIR L. \& Cox. 70 (1956). Another source of local service is the nonscheduled carrier. Some carriers of this type operate under the exemption provision of the act, $\$ 146(b)$, which permits an airline, with Board approval, to provide a particular type of service in the absence of certificate authority. See Large Irregular Air Carrier Investigation, Av. L. REP. (195457 CAB Cas.) II 21879 (Nov, 15, 1955) ; Air Freight Forwarder Investigation, Av. L. REP. (1954-57 CAB Cas.) I 21864 (Aug. 30, 1955). Other nonscheduled carriers operate 


\section{The Community}

Of seventy cities which responded to a Yale Law Journal questionnaire, forty-six stated that their current level of air service was inadequate. ${ }^{74}$ Various shortcomings were said to constitute inadequacy: a total absence of air transportation; the unavailability of flights to a sufficient number of cities; a lack of frequent, through, non- or one-stop flights to and from distant markets; too few flights at convenient hours or with modern aircraft. ${ }^{\text {T5 }} \mathrm{A}$ progressive community, whether primarily an industrial or marketing center, the hub of an agricultural region, or a vacation resort, finds poor service intolerable. ${ }^{76} \mathrm{~A}$ city which ignores the quality of its air commerce may fail to

under temporary "supplemental" certificates authorizing limited flights. See Large Irregular Air Carrier Investigation, 1A Av. L. REP. II 22247 (CAB Jan. 28, 1959).

The service provided by the noncertificated and supplemental carriers is not discussed in this Comment for the following reasons: (1) carriers operating under $\S 416(\mathrm{~b})$ are not subject to the "adequate service" requirement of $\S 404$ (a), see 14 C.F.R. $\$ 291.15$ (1956); (2) the Large Irregular Air Carrier Investigation, No. 5132, CAB, Jan. 28, 1959 , p. 9, has restricted the supplemental airlines to no more than 10 flights per month between any two cities, and the adequacy of their service is thus, for the time being, a moot issue; (3) unpredictable schedules and route patterns preclude characterizing the operations of nonscheduled carriers as "serving" communities; rather, these lines serve particular types of traffic, e.g., military personnel, chartered tours, migratory farm workers and peak season tourist traffic; (4) because they are free to seek maximum profits and to serve any point in the United States, see $i d$. at 20-21, the operations of nonscheduled airlines are most likely to be heavily concentrated in long-haul traffic between major market areas; and (5) the smaller cities have not sought the services of noncertificated or supplemental carriers to remedy local inadequacies, for the sporadic nature of these carriers' scheduling plus the uncertainty of their future position in the industry militates against substantial community reliance on their operations. Replies to the Journal Questionnaire reveal that communities characterizing the adequacy of local service give little if any weight to nonscheduled operations. Such operations were not mentioned in either the context of adequate service or that of community promotional activity.

For general discussions of the nonscheduled carriers, see Large Irregular Air Carrier Investigation, supra; Keyes, Federal Control of EnTrY inTo Air Transportation ch. 5 (1951); Report on AirLines 28-33, 74-110; Cherington, The Essential Role of Largc Irregular Air Carriers, 19 J. AIR L. \& Con. 411 (1952).

74. See introductory footnote $\left(^{*}\right)$ and notes $2-3$ supra. Of the forty-six, nineteen stated that air service had recently deteriorated.

75. The Questionnaire made no attempt to define adequacy but merely asked whether airline service was commensurate with local needs. See APPENDIX, question 5. Those replies detailing the nature of inadequacy cited lack of service in a particular direction, lack of service to a particular community, undependability, poor reservation and information service, insufficient number of flights, unreasonable departure and arrival hours, continual changing of schedules, lack of competition, concentration of service at a neighboring airport rather than the local one, poor intrastate service, poor connecting service, lack of direct or one-carrier service, excessive stops on flights serving the city, inadequate number of available seats, and lack of coach service.

76. See Ogburn, The Soctal Effects of Aviation chs. 24 (manufacturing), 25 (marketing), 29 (agriculture), 19 (recreation) (1946). The Board has stated that marketing centers usually develop more air passengers per unit of population than cities with 
attract industries contemplating relocation or expansion, and may bring about a reduction in the level of business transactions on which local merchants and commercial enterprises depend. ${ }^{\mathbf{7 7}}$ The close relationship between transportation and financial prosperity and the current deterioration in railroad passenger service suggest that the growth of many communities may well depend on improved airline service. ${ }^{78} \mathrm{~A}$ large number of cities are fully cognizant of the dangers lurking in their second-class air service. ${ }^{79}$ Several are considering corrective measures or have begun to rectify deficiencies. ${ }^{80}$ Certain courses have been tried or proposed, the efficacy of which bears examination.

\section{Community-Carrier CoOperation}

\section{Outside the Act}

To promote air transportation, many municipalities have undertaken extensive improvements of their local airdromes. Hangers, repair depots and luxurious terminal accommodations have been offered the airlines, often at belowcost or very low rentals. Communities have constructed landing strips and ramp space sufficient to permit uncongested service by large commercial aircraft. Modern terminal buildings have been erected to attract outbound passenger traffic. All-weather navigational equipment has been installed so that constant air service can be maintained..$^{81}$ And, frequently, localities have en-

balanced economies. See Fort Worth Investigation, No. 7382, CAB, Sept. 23, 1958, p. 33 n.52.

77. See Brief of the City and Chamber of Commerce of Forth Worth to the Examiner, Fort Worth Investigation, No. 7382, CAB, Jan. 21, 1957, pp. 25-28. Arven Sanders, manager of the Raleigh-Durham, North Carolina, airport, has asserted that "two major industrial moves to North Carolina from the Great Lakes area are hanging fire until direct airline service is available." Greensboro Daily News, Jan. 18, 1959, § A, p. 14, col. 7. One community in the southwest, having recently begun construction of elaborate convention accommodations, reports: "In order for this convention facility to serve the purpose for which it is being constructed, it is necessary that air transportation . . . be adequate." QUEstronNaIRE. Another in a southern vacation area states that it has been laboring under a competitive disadvantage because of better air service at a nearby community. Ibid.

78. In reporting on whether surface transportation was satisfactory, fourteen cities claimed that it was not. Eleven specifically mentioned the recent deterioration of railroad passenger service. Ibid.

79. See 1957 CAB ANN. Rep. 5.

80. Twelve cities are contemplating filing complaints with the $C A B$ against their serving airlines. QuestronNARR. Of the seventy cities responding to the Questionnaire, only one had never participated in $\mathrm{CAB}$ proceedings involving service to the community. Many stated that they had at least submitted testimony in every proceeding in which local air service was at issue. Ibid.

81. Buckley, The State of the Scheduled Airlines in Sound Airport Development, 17 J. AIR L. \& CoMr. 22, 23 (1950).

Responding to the question concerning adequacy of airport facilities, forty-five communities reported that improvement plans were underway or nearing completion. Eight 
sured the availability of reasonably priced limousine or taxi service to hotel and business districts.

While a modern physical plant may stimulate traffic, communities also use supplementary promotional devices to develop a constant stream of air commerce. A few cities have instituted vigorous, mass-media advertising campaigns to activate traffic potential. ${ }^{82}$ Civic pride in the local airport is evolied in order to offset the attraction of better service at a nearby community. ${ }^{83}$ And some localities employ aviation consultants who assist carriers by analyzing traffic patterns and measuring passenger demand. ${ }^{84}$ Whatever measures are chosen, they are designed to benefit the airlines and foster a stable, mutually advantageous alliance between carrier and community. ${ }^{85}$ For example, if an airline encounters difficulties in profitably serving a city, landing and terminal fees can be geared to the volume of traffic generated, or reduced until the demand for air transportation increases. ${ }^{86}$ Active cooperation of this sort is

others stated that additions were either contemplated or under discussion. QuestionNAIRE. Facilities that were being constructed or were recently completed include: new terminal building, runway lighting, enlarged parking areas, additional taxi strips, new control tower, high intensity lighting system, communications building, landscaping, enlarged hangers and shops, accommodations for jet service, approach lights, mechanical facilities for baggage handling, restaurant and coffee shop, air postal facilities, additional gate postilions. Ibid.

"Aviation is today an established method of transportation. The future, even the near future, will make it still more general. The city that is without the foresight to build the ports for the new traffic may soon be left behind in the race of competition." Hesse v. Rath, 249 N.Y. 436, 438, 164 N.E. 342 (1928) (Cardozo, J.). For an excellent discussion of the complex of facilities needed in a modern airport, see FREDERTCK 118-22.

82. For discussion of the role of advertising in promoting local air service, see Israel, Television Editorial, The Opportantity at Friendship Airport, WJZ-TV, Baltimore, MId., Dec. 10, 1958. Israel noted that Philadelphia, which spends up to $\$ 50,000$ a year to promote its airport, has exceeded every other city in the country in growth of its commercial air operations.

Widespread use of advertising has also been advocated by a former member of the CAB. See Adams, Future Local Airline Service Depends on State Support, 20 J. AIR L. \& CoM. 403, 413 (1953).

83. One municipality reports that promotion of its local airport has off set the attraction of a neighboring, better-served airfield. QuestionNaIRE. In Baltimore, where Friendship International Airport has long assumed a secondary role because of its proximity to the Washington National Airport, the use of a "Fly Friendship" campaign has been strongly advocated. Israel, supra note 82.

84. Sixteen cities state that aviation consultants have been employed either to assist in airport development or to prepare exhibits and reports for certification proceedings. QUESTTONNAIRE.

85. See Buckley, supra note 81 , at 23 . This relationship can be strengthened by maintaining a constant liaison on mutual problems.

86. In 1955, Ozark Airlines was having difficulty serving the Quad-City Airport at Moline, Illinois, and requested that municipal officials gear landing fees to revenues. When Moline refused the request, Ozark petitioned the Board to serve the area through the nearby Davenport, Iowa, airfield as Davenport had expressed willingness to cooperate with the carrier. The petition was granted. Air Service by Ozark Air Lines, Inc. to 
clearly the most satisfactory means of retaining the required level of air service. ${ }^{87}$

\section{Within the Act}

After a carrier has applied for a new or extended route, the communities to be served can render the carrier invaluable assistance during the certification proceeding. ${ }^{88}$ These cities may appear as either intervenors or supplemental "applicants" $\$ 9$ to demonstrate the inadequacy of present air transpor-

Davenport, Iowa-Moline, Illinois, Av. L. REp. (1954-57 CAB Cas.) If 21880 (1955). See generally Adams, supra note 82, at 414 .

On the other hand, one eastern airport official says that "no amount of local subsidy in the form of cheap rental or elaborate field and terminal construction will necessarily produce improved service." QUESTTONNATRE.

87. Of the twenty-four cities that find local air service adequate, twenty-two report that carrier cooperation is "excellent." (The other two made no comment.) Of the fortysix cities deeming air operations inadequate, only fourteen reported carrier cooperation to be "good." QuestTonNaIRE.

8S. As a general rule, a certification proceeding is initiated by a carrier seeking to add one or more points to its route structure. When an application is received by the $\mathrm{CAB}$, it is assigned a docket number, an examiner is appointed, and a pre-hearing conference held. Representatives of both interested groups-carrier and communities to be served-present their views at the conference. Also, a member of the Bureau of Air Operations, an administrative arm of the CAB, see CAB Statement of Organization, 22 Fed. Reg. 6124 (1957), usually attends and participates actively. The conference defines the issues to be examined in the subsequent certification proceeding. After the examiner submits his report, the Board issues a consolidation order enumerating the relevant issues, and sets dates for the filing of exhibits and a field hearing. Since no one knows the exact scope of a proceeding until the consolidation order is issued, parties affected by the order may submit petitions to intervene or to consolidate pending applications. The Board then rules on these petitions. Issues, parties and applications now being delimited, the proceeding is sent to a hearing examiner. Exhibits are filed, a field hearing is held, and briefs are submitted to the hearing examiner. After his report-known as the initial decision-is handed down, briefs are submitted to the CAB itself and a date is set for oral arguments. Three or four months after these are completed, a decision is rendered. See Westwood, Procedure in New Route Cases Before the Civil Aeronantics Board, 14 J. ArR L. \& CoM. 267 (1947); 1956 CAB ANN. REp. 42.

\$9. Municipal applicants for service proceed under $\S 401$ (h) of the act (now $\S 401$ (g)), which empowers the Board to amend a carrier's certificate upon petition or complaint and after hearing. The term "applicant," as applied to municipalities, has been coined by the Board to refer to those seeking service. The act, however, does not provide for municipal applicants as such. It has been suggested that the act be amended to so provide in order to facilitate Board action on community request. QUESTroNNAIRE. Under the optional-investigation provision of $\$ 401(\mathrm{~h})$, the Board need not take immediate action but may delay a hearing. Such a deferral, it has been charged, is "tantamount to denial," ibid., as this type of interlocutory decision of an administrative agency is not appealable. See CAB v. State Airlines, Inc., 338 U.S. 572, 577 (1950) (Board free to work out application procedures); Western Airlines, Inc. v. CAB, 184 F.2d 545, 548-49 (9th Cir. 1950) (court cannot supervise administrative docket).

Intervenors are of two types. Formal intervenors proceed under rule 15 of the Board's Rules of Practice, 14. C.F.R. $\$ 302.15$ (1956). They become full parties to the proceed- 
tation and the need for inaugural or supplementary service. ${ }^{90}$ Also the community, more propitiously than the airline, can request public officials (such as governors, congressmen and executive-department employees) to appear in support of the proposed service, ${ }^{91}$ although the legality of governmental pressure is currently undergoing judicial examination. ${ }^{92}$ Since a potential for increased traffic must be shown, municipal officials may assume the added responsibility of preparing exhibits on the economic importance of the area and on the strength of commercial ties with municipalities to which service will be provided. ${ }^{93}$ The applying carrier can then concentrate on establishing the expected financial return, the effect of $\mathrm{CAB}$ approval on area and national transportation patterns, the need for competition, and the anticipated effect on the applicant's role within the industry. Municipal support is particularly

ing and may participate in all of its stages. Informal intervenors participate according to rule 14, 14 C.F.R. $\$ 302.14$ (1956), which allows them to present evidence, cross-examine witnesses and submit written statements. Rule 14 does not authorize intervenors to file briefs.

90. Address by Perry H. Taft, National Airports Conference, Nov. 3, 1957; Richmond, Forecasting Air Passenger Traffic by Multiple Regression Analysis, 22 J. Arn L. \& CoM. 434, 435 (1955).

91. Government officials may appear and argue orally by virtue of rule 14, 14 C.F.R. $\S 302.14$ (1956) (informal intervenors). Thirty-two cities report that they have requested government officials and executive department employees to testify on their behalf in certification proceedings. QUESTIONNaIRE. Defense Department officials are frequently approached when the airport to be served is located near a military base. Ibid. One city states that the local post office supplied statistical information on volume of mail, the information to be used as demonstrating the need for service. Ibid. (Prior to 1953, the Post Office Department often intervened in opposition to the granting of extended routes to carriers when they would involve increased subsidy, for subsidy payments were at that time the Post Office Department's responsibility. See, e.g., Additional Service to Kansas Case, 14 C.A.B. 875, 891 (1951). Reorganization Plan No. 10, 67 Stat. 644 (1953), shifted subsidy disbursement to the CAB's budget, leaving only mail-carriage payments with the Post Office.)

92. Capitol Airways, Inc. v. CAB, No. 25434, $2 \mathrm{~d}$ Cir., 1959. Capitol is appealing the Great Lakes-Southeast Serv. Case, 1A Av. L. ReP. If 22211 (CAB Sept. 30, 1958), which denied its application to serve the Chicago-Miami and Detroit-Miami markets. One of the grounds being urged for reversal is that Capitol was prejudiced at the oral argument before the Board by the appearance of six members of Congress whose testimony, it claims, amounted to illegal interference with the functions of an administrative agency. See Brief for Petitioners, pp. 14-24, Capitol Airways, Inc. v. CAB, supra. See also Rizley, Some Personal Reflections After Eight Months as Chairnan of the Civil Aironautics Board, 22 J. AIR L. \& CoMr. 445, 450 (1955) (criticizing congressional interference and pressure).

93. "[A] community, if it is to be successful in prosecuting its case, must participate in all stages of the proceeding. In connection with documentary material, particularly exhibits, the community must go first class because nothing is more discouraging to the Examiner and the members of the Board than a documentary record filled with "junk.", Address by Perry H. Taft, National Airport Conference, Nov. 3, 1957. See also Richmond, supra note 90 (activities of one city in certification proceeding). 
vital when sufficient passenger demand is uncertain, for the $C A B$ has often held carrier-city cooperation a prerequisite to service extensions in marginal traffic areas. ${ }^{94}$

The community which closely coordinates its activities with those of an applying carrier, however, may encounter many disadvantages. For example, when the airline is induced to apply for a route extension through an offer of airport facilities at below-cost rates, a subsequent increase in landing and rental fees is quite likely to strain relations.95 Or, the relationship may end if the city later supports the entrance of competitive service, for the once-preferred carrier may deem such support inconsistent with the initial partnership. ${ }^{00}$ Analogously, if a number of applicants seek a route extension, the community which allies itself with one of them may later find this approach to have been imprudent. The favored applicant may use the stop only as a temporary stepping-stone into a major market area; $; 7$ and the city whose cooperation was so assiduously elicited may soon find its level of service sharply diminished as equipment is rerouted to more profitable long-haul flights. ${ }^{98}$ In this situation, municipal officials would have been better advised to remain

94. See, e.g., Seven States Area Investigation, 1A Av. L. REP. I 22226, at 14320 (CAB Dec. \&, 1958) (emphasizing mutual carrier-community responsibilities) ; cf. Westwood, supra note SS. One city, noting that its level of air service was geared to the financial health of its only authorized carrier, made it a policy to provide strong support to every petition of the carrier for a route extension which offered promise of improving the airline's financial position. QUeSTIONNAIRE.

95. If the community is successful in obtaining scheduled air transportation service from the airline which has been so "helpful" to it, the community not only gives that airline the key to the city but a more or less free ride at the airport as well. Such a temporary marriage of convenience is bound to end in an unsatisfactory future divorce, with long range bad feelings existing between the community and the airline.

Address by Perry H. Taft, National Airport Conference, Nov. 3, 1957.

96. This possibility is well illustrated by the recent aviation turmoil in Raleigh-Durham and Greensboro, North Carolina. Distressed by the efforts of an initially favored local-service carrier to block the entrance of competitive trunkline service, Greensboro first considered revoking the local-service carrier's landing permit, then decided to petition the $\mathrm{CAB}$ to withdraw the certificate of the local-service carrier if its presence would prevent better trunkline service. Raleigh-Durham was also considering the possibility of taking action against the local-service carrier in light of the latter's apparent determination to block trunkline flights to the midwest. See Greensboro Daily News, Jan. 18, 1959, $\S$ A, p. 14 , col. 5 ; id., Jan. $21,1959, \S$ B, p. 1, col. 7.

97. "Here again, bad feelings between the community and the airline are engendered, particularly where the community subsequently discovers that it was being 'used' by the airline as a crutch to assist the airline in actually obtaining a route extension to a point beyond that community." Address by Perry H. Taft, National Airport Conference, Nov. $3,1957$.

98. Noting a recent decline in the service provided by its two authorized trunklines, one city stated that the carriers were seeking long-haul routes. QUESTIONNAIRE. Another charged that the authorized trunkline serving the community had a "gravy train" dur- 
nonpartisan, especially since their choice undoubtedly carried great weight with the $\mathrm{CAB}$. Hence, many communities remain independent in route-allocation proceedings, and confine their role to demonstrating a need for more service.99 This approach enables city officials to avoid alienating a particular carrier, yet to present their own views vigorously. ${ }^{100}$

Obviously, however, the airlines may refuse to take the initiative in applying for route extensions. Equally obviously, a community then cannot limit its function to participating in proceedings originated by a carrier. ${ }^{101}$ In fact, even the active promotion of air travel and the development of ground facilities may fail to entice the carriers, for the lure of long-haul profits may make them oblivious to financial and moral suasion on the local level. ${ }^{102}$ Furthermore, if a city is already on the air map, its most effective course of action may not be procuring the services of a competitive carrier but ensuring that presently authorized airlines maintain an adequate level of operations. In any event, whether a municipality seeks first-carrier or competitive service, or a Board order directing an improvement in the quality of transportation presently being furnished, the community can turn to the Civil Aeronautics Act for relief.

ing its tenure and could have developed an excellent level of traffic, but that the line considered serving the city a nuisance. Accordingly, the city reported it would be happy to have the $\mathrm{CAB}$ replace the trunkline with a local-service carrier. Ibid.

99. According to one city :

We believe that since it is the function and the duty of the Civil Aeronatics Board to designate the appropriate carrier to provide the needed service, it would be presumptuous and psychologically unwise for us to attempt to pre-empt this function. Then, too, it may appear that the civic party is attempting to "carry water" for the carrier. It can very easily prejudice the civic party. We prefer to concentrate our efforts on demonstrating our service needs.

QUESTIONNAIRE.

100. According to an aviation attorney for a southwestern city active in the promotion of adequate air service:

The program which the city ... adopted some six or eight years ago was that we would never try to voice to the $C A B$ what air line would render a given service; instead we would present our facts to the CAB showing the need for service and leave the question to the CAB and the air lines to figure out who can render a given service. This has left our city completely free to present its own views vigorously and independently. As a result I think we have the good will of all the air lines.

QUESTIONNAIRE.

101. For example, one community does not wait for carriers to make application for services which the city needs, but inaugurates its own proceedings instead. QuestionNaIRE. And see Tucson Airport Authority, Av. L. Rep. (1954-57 CAB Cas.) f 21977 (1956) (community originated proceeding) ; Service to Phoenix Case, Av. L. ReP. (195457 CAB Cas.) II 22079 (1957) (same).

102. See Israel, supra note 82 (["Baltimore's] magnificent terminal building echoes with emptiness. Friendship [Airport] has been scorned by the airlines. It has been forgotten by the Federal Government. It has even been neglected by the people of Baltimore. They have long since lost faith in the airport's meager service."). 


\section{The Community and Carrier in Opposition}

\section{Securing New Service}

Communities may seek improved service under section $401(\mathrm{~h})$ of the act (now section $401(\mathrm{~g})$ ). This provision allows the $C A B$, upon petition, complaint, or its own motion, and after notice or hearing, to alter or amend any certificate by adding or deleting stops whenever the public convenience and necessity so require. ${ }^{103}$ Despite the requirement in section 401 (d)(1) that the affected airline be "fit, willing, and able" to perform, opposition on the part of a carrier does not preclude amendment of its certificate. On the strength of an airline's original application for a certificate, the line is conclusively presumed to be willing to serve a revised route pattern not materially different from that initially specified. ${ }^{104}$ Consequently, the Board has authority to order a recalcitrant carrier to serve hitherto unscheduled points as intermediate stops. A city may nevertheless encounter difficulty in persuading the $\mathrm{CAB}$ to proceed under section $401(\mathrm{~h})$, for the Board is under no compulsion to act immediately on a community's petition. ${ }^{105}$ Moreover, to amend a certificate is not to guarantee that service will be provided; the airline still retains its independence in initiating and maintaining service ${ }^{106}$ —subject, however, to the general obligations imposed by section 404(a)'s "adequate service" provision.

\section{The Section 401(h) Cases}

Despite its shortcomings, section 401 (h) has been extensively employed. ${ }^{107}$ Indeed, with intersecting air routes virtually blanketing the country, few cities

103. See Netterville, Local Service Airlines: Trunkline Suspensions in Aid of the Local Service Experiment, 26 So. CaL. L. Rev. 229, 250-61 (1953) (discussion of the legislative background and constitutionality of section $401(\mathrm{~h})$ ). See also THomas 11-118. For a review of the Board's power under $\$ 401(\mathrm{~h})$, see Braniff Route Extension Investigation, Av. L. REP. (1954-57 CAB Cas.) II 21974, at 14691 (1956) ; Note, Compulsory Inanguration and Extcusion of Air Carricr Rontes, 38 Geo. L.J. 81 (1949).

104. CAB v. State Airlines, Inc., 338 U.S. 572 (1950); Southeastern States Case, 8 C.A.B. 716, 720 (1947); Panagra Terminal Investigation, 4 C.A.B. 670, 673 (1944). In applying for a certificate amendment, carriers often insert a "catch-all" clause requesting that they be considered as applicants for any and all new routes which the Board may find required by public convenience and necessity. See, e.g., Seven States Area Investigation, 1A Av. L. REP. I 22226, at 14302 (CAB Dec. 8, 1958). The Board frequently relies on general prayers in applications when it awards carriers certificates authorizing service routes not specifically requested. Ibid.

105. See note 89 supra. One aviation attorney has remarked: "Generally, I would say that it would be best for a municipality to interest an airline in serving it, and have that airline request authority from the Civil Aeronautics Board to serve the city in question. ... [W]ithout the support of an airline, there might be some considerable delay in securing a hearing." QUEsTIONNAIRE.

106. See notes 41-51 supra and accompanying text.

107. See, c.g., Service to Phoenix Case, Av.. L. Rep. (1954-57 CAB Cas.) II 22079 (1957) ; Tucson Airport Authority, Av. L. Rep. (1954-57 CAB Cas.) T 21977 (1956). 
are so isolated that they could not obtain new-carrier service by having an outstanding certificate amended. ${ }^{108}$ The recent Service to Ely, Nevada case is illustrative. $^{109}$

Ely's population is 3,558 ; its location, a desert 250 miles southwest of Salt Lake City. Though geographically remote, the town is the center of extensive oil and copper extraction operations. Before 1955, Ely had no commercial passenger transportation of any sort. It had a small airport, however, which it was willing to expand if airline service were authorized. Seeking such service, the town's representatives approached United Airlines officials; the latter declined to apply for an amendment of United's certificate on account of Ely's marginal traffic potential. Ely then petitioned the CAB under section $401(\mathrm{~h})$ for an amendment of United's certificate. The carrier immediately intervened in opposition, and the hearing examiner accepted its contention that traffic potential was too limited to support the proposed operation. ${ }^{110}$ After extensive investigation, the $\mathrm{CAB}$ reversed.

Although the Board agreed with the examiner that United would be likely to sustain losses initially in serving Ely, it found the probable deficit to be less than the examiner had estimated.111 The town's extreme isolation and the absence of any commercial surface transportation were given great weight.112 The Board also observed that the region's substantial copper and oil operations indicated significant traffic potential. ${ }^{113}$ Ely's willingness to provide expanded airport facilities was taken as a satisfactory expression of the town's support of air service. ${ }^{114}$ The CAB concluded that an experimental period of air transportation was warranted, and authorized United to initiate service into Ely for a trial period of two years. Acquiescing, the airline cooperated and currently provides two daily round-trip flights-one connecting with Salt Lake City, the other with Elko, Nevada.115

Another decision that should have far-reaching effects for the small community seeking inaugural service from an uncooperative airline is the Seven States Area Investigation. ${ }^{116}$ The CAB there announced a "use it or lose it"

108. Air-route maps for trunklines and local-service carriers as of June 30,1957 , can be found in 1957 CAB ANN. REP. between pp. 2 and 3.

109. Av. L. REP. (1954-57 OAB Cas.) โ 21812 (1955).

110. The foregoing information is taken from Service to Ely, Nevada, No. 6528, CAB, March 17, 1955, app. pp. 2-3.

111. Av. L. REP. (1954-57 CA.B Cas.) If 21812, at 14218 (1955).

112. Ibid. Where terrain is difficult and surface transportation slow, the need for air transportation becomes greater. All Am. Aviation, Inc., 2 C.A.B. 133, 151 (1940).

113. Av. L. REP. (1954-57 CAB Cas.) II 21812, at 14218 (1955).

114. Ibid.

115. Offictal Airline Guine C-340, C-344 (March 1, 1959).

116. 1A Av. L. REP. If 22226 (CAB Dec. 8, 1958). The investigation was instituted by the Board upon the petition of North Dakota, South Dakota, Minnesota, Iowa, Nebraska, Wisconsin, and Illinois; these states sought a determination of the local air-service needs in their general area. The proceeding embraced petitions by four local air carriers for route extensions, requests by fifty-four city applicants, and applications of two trunklines to suspend or delete service at many points throughout the area. Id. at 14293 . 
policy in authorizing local air transportation for cities in the relevant area, many of which were without any service. ${ }^{117}$ Specifically, the Board reserved the right to suspend or delete service after eighteen months at any point with an average of less than five enplaned passengers per day. ${ }^{118}$ Communities with marginal traffic potential were thus given an opportunity to demonstrate their ability to support local air service which they could not obtain through orthodox certification proceedings. ${ }^{119}$ This decision has practical limitations, however. While it should prove helpful to a community lacking air service, a city already on the national air map may encounter well-nigh insurmountable difficulties in generating sufficient demand to support an additional airline. Most likely, therefore, such a city will find proceedings against its presently authorized carriers the most feasible method of rectifying local inadequacies.

\section{Improving Present Service: The Section 404 Cases}

A city which receives unsatisfactory service from its certificated airlines is theoretically able to obtain redress under the Civil Aeronautics Act. By requiring every certificated carrier to provide "adequate service," section 404(a) attempts to ensure a satisfactory level of operations. ${ }^{120}$ And, notwithstanding adequacy, section 404(b) prohibits an airline from granting any undue preference or engaging in any unjust discrimination when serving different communities. ${ }^{121}$ This command presumably controls both airline scheduling policies $^{122}$ and $\mathrm{CAB}$ approval of a route extension. ${ }^{123}$ To date, however,

117. Id. at 14319. A number of the certificates were granted on a temporary basis to facilitate subsequent Board reappraisal. Id. at 14297.

118. Seven States Area Investigation, No. 7454, CAB, Dec. 8, 1958, pp. 137-38. The average number of passengers enplaned was to be computed without regard for the first six months of service. Id. at 138 n.158.

119. Id. at 136.

Many of these communities will be receiving air service for the first time. Others, whose air service has been confined to rather perfunctory and inadequate schedules provided by trunkline carriers as part of their long haul flights, will be given an opportunity to prove their greater traffic generating ability with local service better adapted to their transportation needs.

1A Av. L. Rep. If 22226, at $1+320$ (CAB Dec. 8, 1958).

In granting or denying air service to the applicant cities, the Board was primarily influenced by the following considerations: the volume of probable traffic which would be developed, the cost of the service to the carrier and the Government, the location of the community in relation to presently available air service, the length of detour from present routes necessary to serve a particular city, the cost involved therein, and the isolation of a community from its primary trade centers. Id. at 14293 .

120. The section is quoted in part at note 39 supra.

121. The section is quoted in full at note 39 supra.

122. Fort Worth Investigation, No. 7382, CAB, Sept. 23, 1958, p. 32 n.51, discussed notes 139-72 infra and accompanying text. But see Philadelphia-Transatlantic Serv. Case, Av. L. REP. (1951-54 CAB Cas.) II 21454, at 16393 (1952), discussed note 172 infra.

123. Greensboro-High Point Airport Authority v. $\mathrm{CAB}, 231$ F.2d 517, 521 (D.C. Cir. 1956), discussed notes 134-38 infra and accompanying text. 
sections 404(a) and (b) have not achieved effective expression, and have therefore afforded the disadvantaged city little practical protection. ${ }^{\mathbf{1 2 4}}$

\section{The Grand Rapids, Toledo and Greensboro Cases}

Grand Rapids. Increasing dissatisfaction with airline practices has led several communities to intervene in, or to institute, proceedings before the $\mathrm{CAB}$ in order to bring charges of inadequate service, discriminatory practices, or both. Among the more significant section 404 (a) controversies awaiting CAB resolution is the Flint-Grand Rapids Adequacy of Service Investigation. ${ }^{125}$ Grand Rapids, Michigan, currently depends upon one trunk carrier-Capital Airlines-for air transportation to distant points with which that city has substantial commercial ties. ${ }^{126}$ Faced with Capital's decision to abandon through

124. Shortly after the passage of the act, one commentator pointed out that the Board must "in the near future" determine what constituted "adequate service," preferably by investigating carrier operations. PUFFER 164. Indeed, the Board itself recognized that the act authorized it to order adequate service to certificated stops should the need for such action arise. United Air Lines Transp. Corp., I C.A.A. 723, 730 (1940). Yet, it was not until 1958 that the $C A B$ rendered a decision interpreting the mandatory requirement of $\S 404(a)$. See Brief of Grand Rapids, p. 1, Flint-Grand Rapids Adequacy of Service Investigation, No. 9177, OAB, 1959 ("In only two cases has the Civil Aeronautics Board been called upon to pass directly on the question of what constituted 'adequate' service within the meaning of Section $404(\mathrm{a})$...."). The two cases referred to were the Fort Worth Investigation, 1A Av. L. REP. If 22205 (CAB Sept. 23, 1958), discussed notes 139-72 infra and accompanying text, and the pending Washington-Baltimore Adequacy of Serv. Investigation, No. 8148, CAB, 1959, discussed note 155 infra.

As for $\$ 404(\mathrm{~b})$, the Reopened Charleston-Columbus Case, 1A Av. L. Rep. \} 2 2 1 5 3 (Jan. 16, 1958), discussed notes 134-38 infra and accompanying text, and the Fort Worth Investigation, supra, are the only significant decisions on that section. The Eoard has stated that investigations will be instituted only when a reasonable cause for complaint exists and solution to the adequacy problem cannot be arrived at through informal means. 1956 CAB ANN. Rep. 12.

An Investigation of Coach-Type Service in Certain New York Markets, No. 9973, $\mathrm{CAB}, 1959$, now pending before the CAB, is the only Board-initiated investigation of carrier compliance with section 404(a). Ten trunklines and one local service carrier have been made parties to the proceeding. Though the specific purpose of the investigation is to determine whether coach service available from New York to various markets is legally adequate, and what action would be necessary, the Board intends to formulate standards for the carriers' guidance in providing adequate coach service in other markets. The initial decision of the hearing examiner is pending.

The Board recently added to its economic regulations rules applicable to adequacy-ofservice complaints. See 14 C.F.R. $\$ 302.700-.705$ (Supp. 1959), 22 Fed. Reg. 10439 (1957). These rules provide that a proceeding to determine adequacy may be instituted by the filing of a petition or complaint. The parties to the proceeding shall be the complainant, the carrier(s) challenged, Bureau Counsel, and any others permitted to intervene. If the air carrier complained against does not satisfy the complaint and there shall appear to be any reasonable ground for investigation, the Board will look into the charges.

125. No. 9177, CAB, 1959.

126. Grand Rapids is also served by two feeder lines-North Central and Lake Central-neither of which is involved in the proceeding. See Offictal AirLine Guide cols. 420-23 (Quick Ref. ed., March 1, 1959). 
service to these areas and to substitute the equivalent of a feeder-line connection instead, Grand Rapids has filed a complaint alleging that Capital is shirking its section 404 (a) obligations. ${ }^{127}$ The city requested that a competitive airline be authorized on the theory that certain qualitative inadequacies such as inefficiency and undependability could not be remedied by a CAB order. Although this request was summarily denied, ${ }^{128}$ the Board did institute an investigation to determine whether Capital is providing adequate service to Grand Rapids and, if not, to decide what specific improvements are needed. The CAB must now formulate a standard of adequacy for a carrier holding a monopoly on a community's trunk carriage.

Toledo. In the Toledo Adequacy of Service Investigation, Capital is again the principal defendant and section 404(a) again underlies the controversy. ${ }^{120}$ But, unlike Grand Rapids, this case is set in a competitive context. ${ }^{130}$ According to the complaint, Capital, in virtually terminating service between Toledo and Chicago, Cleveland, New York and Philadelphia, failed to put competitive pressure on the four trunklines also serving these points. ${ }^{131}$ Thus, Toledo alleges, Capital has retarded the normal growth of air travel ${ }^{132}$ by

127. "It is apparent from this schedule pattern that Capital Airlines is providing essentially a local service operation for Grand Rapids." Brief of Grand Rapids to CAB Examiner, p. 26, Flint-Grand Rapids Adequacy of Service Investigation, No. 9177, CAB, 1959. Grand Rapids has stressed the statement of one of Capital's witnesses at the field hearing: "In effect, we are operating our own feeder system." Ibid.

The CAB Bureau of Air Operations, a frequent participant in certificate and service proceedings, see note $8 S$ supra, concluded that Capital's service from Grand Rapids to Detroit, Minneapolis/St. Paul, New York and Milwaukee was in fact inadequate. Additionally, the Bureau felt that Capital's "on time" performance at Grand Rapids was inadequate. See Brief of CAB Bureau of Air Operations to Examiner, pp. 46-47.

Capital Airlines is defending on the grounds that load factors at Grand Rapids are low in comparison with the large volume of service being provided, that additional service would not be economically feasible, and that the pattern of service provided is designed best to meet the community's over-all transportation needs. Brief of Capital Airlines, Inc., to Examiner, pp. 3-5.

128. CAB order no. E-12254, March 14, 1958. Despite this setback, Grand Rapids has requested the hearing examiner to find that a need for a second trunkline carrier exists, and that a prompt hearing on the matter should be instituted by the Board. Under $\$ 401$ (h), Grand Rapids has also filed an application for amendment of the certificate of public convenience and necessity of Northwest, United, Trans World or American Airlines in its move to obtain additional trunkline service. Brief of Grand Rapids, supra note 127 , at p. 54.

129. No. $8851, \mathrm{CAB}, 1959$. The initial decision of the hearing examiner has not yet been handed down.

130. Toledo is served by Lake Central, United, Trans World, Eastern, Delta, and Capital Airlines. Official AIrLINe Guide cols. 1100-05 (Quick Ref. ed., April 1, 1959).

131. In September 1953, Capital accounted for $15.6 \%$ of the traffic between Toledo and its four principal markets. In the same month in 1957, Capital accounted for only 3\%. Exhibits of City of Toledo and the Toledo Chamber of Commerce, Ex. No. Tol-6, Toledo Adequacy of Service Investigation, No. 8851, CAB, Dec. 3, 1958.

132. Id. at 14-16. "[T] he fact that Toledo's traffic potential has not been realized and that its traffic, particularly in its principal markets, has not experienced normal growth 
inducing its competitors to curtail their level of service. ${ }^{133}$ Toledo therefore raises the complex question whether section 404(a)'s "adequate service" mandate encompasses a failure to compete in a multi-carrier community.

Greensboro. One of the two categories of discrimination proscribed by section 404(b) was at issue in the Greensboro, North Carolina, case. ${ }^{134}$ Allegedly, a proposed route-certificate amendment preferred one community over another. The route at issue (limited to the relevant cities) was that flown by Eastern Airlines from Miami to Charlotte, N.C., to Greensboro, to Charleston, W. Va., and then to Detroit. Eastern petitioned the CAB for permission to add Toledo and Columbus, Ohio, as intermediate stops on this route beyond Charleston. The hearing examiner authorized the proposed extension only on direct flights between Charlotte and Detroit; as a result, service by Eastern between Greensboro and the added points was precluded. ${ }^{135}$ Greensboro claimed that "splitting" Eastern's route at Charlotte gave that city an illegal preference and worked an unjustified discrimination against Greensboro. ${ }^{136}$ The CAB's final decision, affirmed on appeal, stated that the discrimination which the new route occasioned was balanced by accompanying public benefits, that Charlotte surpassed Greensboro in need for and probable use of the added service, and that no particular competitive relationship was shown to exist between the two cities. ${ }^{137}$ Accordingly, the extension was authorized.

rates is traceable to the absence of effective competition." Id. at 15-16. The number of passengers between Toledo and its four principal markets increased only $1.4 \%$ between 1955 and 1957, while the overall national growth of air traffic increased $23.9 \%$. Id. at 15 . And Toledo's income and population increase was above the national average. $I d$. at 7 .

133. During 1955-57, traffic in Toledo increased $1.4 \%$ while service from Toledo to the four major market areas over which Toledo was most concerned declined 25 to $100 \%$. Exhibits of City of Toledo, Toledo Adequacy of Service Investigation, No. 8851, CAB, Dec. 3, 1958, pp. 14-15.

134. Reopened Charleston-Columbus Case, 1A Av. L. REP. $\{22153$ (CAB Jan. 16, 1958), aff'd sub nom. Greensboro-High Point Airport Authority v. CAB, 262 F.2d 689 (D.C. Cir. 1958).

135. Prior to the proceedings before the hearing examiner, both Charlotte and Raleigh-Durham, North Carolina, were denied leave to intervene on the grounds that their interests would not be affected; however, they were allowed to participate informally under rule 14 of the Board's Rules of Practice. Order Granting and Denying Intervention, CAB Order No. E-7980, Dec. 18, 1953.

136. Greensboro had intervened after the hearing examiner's decision. Order Granting Intervention, CAB Order No. E-8673, Sept. 30, 1954. Greensboro then appeared at the oral argument before the $\mathrm{CAB}$ and raised the issue of discrimination. The Board, however, affirmed the decision of the hearing examiner, Charleston, W. Va. and Columbus, Ohio, Case, Av. L. Rep. (1954-57 CAB Cas.) If 21795 (1955). Greensboro's petition for rehearing was denied. Order Denying Petition for Reconsideration, CAB Order No. E-9015, March 14, 1954.

137. After the Board affirmed the hearing examiner's decision, Greensboro appealed to the United States Court of Appeals for the District of Columbia Circuit. The Board's decision was reversed on the grounds that Greensboro had not received an answer to its charge of discrimination; that this issue was relevant to the Board's ultimate decision as 
The Board's decision is conclusive, however, only as to discrimination authorized in the amended certificate; if Eastern subsequently gives Charlotte preferential service unrelated to the approved route, Greensboro may file a complaint against the airline charging a different section 404 (b) violationoperational discrimination. ${ }^{138}$

\section{The Fort Worth Case}

Clearly the most significant of the recent CAB decisions, the Fort Worth Investigation ${ }^{139}$ fuses many elements of the Toledo and Greensboro controversies. A multi-carrier community there combined a section 404 (b) charge of discrimination with a section 404(a) allegation of inadequate service. Fort Worth did not attack a particular carrier but instead challenged the service provided by all its authorized airlines. ${ }^{140}$ Under section $404(\mathrm{~b})$, Fort Worth claimed that every carrier certificated to serve both Forth Worth and Dallas concentrated its flights at the Dallas airport and thereby unduly preferred

to what public convenience and necessity required; and that failure to answer the claim of discrimination would prejudice Greensboro in its effort to obtain judicial review. Greensboro-High Point Airport Authority v. CA.B, 231 F.2d 517 (D.C. Cir. 1956). The Board then reopened the proceeding for further hearings and presentation of evidence before a hearing examiner. Reopened Charleston-Columbus Case, 1.A Av. L. REP. II 22153, at 14060 (CAB Jan. 16, 1958). The examiner had found, inter alia, that Charlotte stubstantially outweighed Greensboro in economic importance and in need for the service in question, that no particular competitive relationship existed between Charlotte and Greensboro, that Greensboro had no need for service to Columbus and Toledo, and that providing direct service to Columbus from Greensboro would occasion substantial diversion from and increased subsidy need for the local carrier presently serving the route. Id. at 14060-61. The Board adopted the hearing examiner's findings and stated that Greensboro's competitive relationship did not transcend the ordinary type of latent competition between most cities in the country; that there would be no substantial adverse effect upon Greensboro if Eastern's route were split at Charlotte; and that, even if two cities possessed the same traffic potential, discrimination could be justified by geographical integration with the serving carrier's route structure. $I d$. at 14060-65. Upon a second appeal, the Board's decision was affirmed. Greensboro-High Point Airport 'Authority v. OAB, 262 F.2d 689 (D.C. Cir. 1958). Compare Fort Worth Investigation, No. 7382, CAB, Sept. 23,1958, p. $33 \mathrm{n} .52$ (dissimilarity in economic activity tends to minimize the importance of a competitive relationship).

138. Cf. Greensboro-High Point Airport Authority, 231 F.2d 517, 521 (D.C. Cir. 1956). In Application of Greensboro-High Point Airport Authority for Additional Air Service, No. 6880, CAB, 1959, Greensboro has alleged that the trunkline service at the local airport is not adequate and is discriminatory. The application has not been set for hearing. QUesTIONNAIRE.

139. Fort Worth Investigation, 1A Av. L. ReP. I 22205 (OAB Sept. 23, 1958). The opinion was fully reprinted in the CAB mimeograph opinion and extracted in the $C C H$ Aviation Law Reporter. Citations will be to the Aviation Law Reporter whenever possible and to the mimeographed opinion, CAB Dkt. No. 7382, when that is the only source.

140. The issues as framed by the Board were whether "any" carrier had failed to provide adequate service, and whether "any" carrier should by appropriate order be compelled to comply with $\S 404$ (a). No. 7382, CAB, Sept. 23, 1958, app. 1. 
that city. ${ }^{141}$ The Board refused to decide the discrimination issue, ${ }^{142}$ but it did utter significant dicta on the interrelationship of sections 404 (a) ("adequate service") and 404(b) ("discrimination"). The CAB stated that, while inadequate service and discriminatory practices were distinct concepts and one could exist without the other, ${ }^{143}$ discrimination might be indicative of inadequacy. Therefore, the Board said, in assessing the section 404(a) requirements of a particular community, it would consider the quality of air transportation typically available to similar communities. ${ }^{144}$ Still, the Board cautioned, even if two communities were identical in all respects, a difference in service levels would not by itself demonstrate inadequacy, since operations at the favored city might be more than adequate. The $\mathrm{CAB}$ then laid down a more far-reaching rule-that the air services of two communities, however proximate, will not be compared when their economic structure and traffic potential are significantly dissimilar. ${ }^{145}$ Finally, the Board noted, the benefit accruing to one city from flights at a neighboring community should be considered in determining whether service is adequate, and should be deemed to offset, if not negate, the discriminatory nature of disproportionate service attacked under section 404 (b). ${ }^{146}$

Turning to the section 404(a) issue in Fort Worth, the Board construed that section to impose only a minimum standard of service, that is, to require the reasonable accommodation of existent traffic demand. ${ }^{147}$ Hence, the fewer arriving and departing passengers an airport has per day, the greater freedom

141. See Brief for Fort Worth to the Examiner, p. 31, Fort Worth Investigation, 1A Av. L. REp. If 22205 (CAB Sept. 23, 1958). Dallas and Fort Worth are approximately thirty-one miles apart and are served by two airports. Amon Carter Field (Fort Worth International Airport) is nineteen miles from both Fort Worth and Dallas; Love Field (Dallas) is eight miles from Dallas and thirty-one miles from Fort Worth. No. 7382, CAB, Sept. 23, 1958, app. 3, 13. Carter is only six years old, is strategically located between the two cities, and is claimed to be a superior airport. See Brief for Fort Worth to the Examiner, pp. 6-7, 21-22, supra.

142. 1A Av. L. REP. \2 22205 , at 14203.

143. For instance, a city whose services are legally adequate might nevertheless be the object of discrimination in favor of another city which enjoys an undue or unreasonable advantage over it in service; conversely, service at a city might be legally inadequate even if its only significant competitor suffers from similarly inadequate service.

No. 7382, CAB, Sept. 23, 1958, p. 32 n.51.

144. Id. at 32-33. See also Reopened Charleston-Columbus Case, 1A Av. L. REP. II 22153, at 14064 (CAB Jan. 16, 1958).

145. 1 Av. L. Rep. গ 22205 , at 14204.

146. "[W]hile continuous improvements at Love, unmatched by proportionate changes at Carter, might in time result in disproportionate benefits to Dallas of a discriminatory nature, they would also confer substantial benefits on Fort Worth and accordingly would tend to advance rather than detract from the adequacy of Fort Worth's service. . .." Ibid. But see note 188 infra.

147. 1 Av. L. REP. $\{22205$, at 14201. In discussing adequacy, the Board examined separately the various routes which Fort Worth charged were inadequately served. Each 
a carrier has in legally curtailing operations. Nonetheless, recognizing the temporary nature of adequacy, the Board also observed that sufficient service may become inadequate if future deterioration is not warranted by reduced traffic, or if an airline fails to correlate improved service with community expansion. ${ }^{148}$ Still, "adequate service" emerged from the Fort Worth decision merely as a safeguard against poor service, and not as a standard facilitating the local development of air transportation. ${ }^{149}$ Section $404(a)$ is of no avail, therefore, unless an actual insufficiency can be demonstrated. It is bootless to show no more than the feasibility of a proposed improvement in service, or the benefits which improvement would bring. ${ }^{150}$

In applying its limited interpretation of section $404(\mathrm{a})$, the $\mathrm{CAB}$ rejected Fort Worth's request for a finding of across-the-board inadequacy, and held that "adequate service" must always be appraised destination by destination. ${ }^{151}$ The Board also stated that the legal sufficiency of a given carrier's service cannot be determined by considering that carrier's operations alone. Rather, to ascertain whether the demand for air transportation to a particular market is being met satisfactorily, the CAB will review in the aggregate not only the services furnished by all of a complainant community's authorized carriers but also the flights scheduled from any readily accessible neighboring airport. ${ }^{152}$ Moreover, according to the Board, the "adequate service" standard does not oblige a carrier to furnish express or limited-stop or through flights, provided such flights are available on another airline at either the local or a nearby airport. ${ }^{153}$ Even if an allegedly dilatory carrier received its initial grant of authority because it was expected to provide a competitive stimulant, its indolence is excusable when other airlines dominate the market and absorb all available traffic. The terms of the noncompeting airline's initial grant are not defeated, the Board reasons, because that airline is in effect a residual rival able to re-enter the market with vigor should the established carriers fail to provide service responsive to the public's needs. ${ }^{154}$ Thus, if the complex of

was considered in terms of satisfactory accommodation of demand. For example, the Board noted that the level of service maintained by Delta between Fort Worth and New Orleans was "ample" on the basis of surveys and estimated demand. Id. at 14200-01.

148. Id. at 14201. The Board stated, however, that deterioration was not tantamount to inadequacy, for surrounding circumstances might warrant a decline in the quantity or quality of a particular service. No. 7382, CAB, Sept. 23, 1958, p. 20 n.24.

149. Id. at 20.

150. 1 Av. L. REP. $\llbracket 22205$, at 14201 . "In other words the adequacy requirement does not automatically come into play merely because an improvement could be justified." No. 7382, CAB, Sept. 23, 1958, pp. 20-21.

151. "[W] mean that if inadequacy cannot be found in particular markets, no finding of general inadequacy in the city's service can be made." 1 Av. L. REP. $\{22205$, at 14199.

152. Id. at 14200 .

153. Ibid. If, however, the inadequacy were of a "positive or affirmative sort," such as bad food, undependability, or discourteous treatment, the services of another carrier would be irrelevant. Ibid.

154. No. 7382, CAB, Sept. 23, 1958, pp. 10-11. 
flights flown by all carriers from all geographically related airports (for example, Fort Worth and Dallas) provides an area with adequate air transportation, no one carrier can be held to violate section 404(a) regardless of its level of operations..$^{155}$

The Fort Worth doctrine ignores the community's objective of promoting traffic potential. Under that doctrine, carriers need serve only actual traffic, and need not develop increased demand through a more extended pattern of air transportation. ${ }^{158}$ The $\mathrm{CAB}$ emphasized that the level of service at Fort Worth was sufficient because the airlines could accommodate the average number of enplaned passengers per day on the routes in question. ${ }^{157}$ While based on accurate statistics, this conclusion minimizes the fact that better service at the Dallas airport was attracting Fort Worth traffic which would board locally were flights available. ${ }^{158}$ Furthermore, irrespective of the other airport,

155. "The protection of the public's right to adequate air service between two places that are authorized to be linked by competing carriers does not require that each carrier's service in itself be enough to meet the public's needs, but rather that the aggregate of services offered between the two points be adequate to do so." 1 Av. L. REP. $\{22205$, at 14200 .

A second $\S 404$ case, Washington-Baltimore Adequacy of Serv. Investigation, No. 8148, CAB, 1959, is now awaiting Board decision. Oral argument was had on November $6-7,1958$. Baltimore has charged serving carriers with inadequate service in violation of $\S 404$ (a) and with transgressing $\S 404$ (b) by unjustly discriminating against Baltimore in favor of nearby Washington. The carriers involved are Alleghany, American, Capital, Delta, Eastern, National, Northeast, Trans World, and United Airlines. The Bultimorc litigation is substantially similar, both legally and factually, to the Fort Worth case. Each city has charged "across-the-board" inadequacy on the part of all the serving airlines, and the issues of adequacy and discrimination involve the services at a nearby airport. Thus, the $C A B$ will have an opportunity to reappraise the doctrines announced in Fort Worth. For further discussion of the Baltimore case, see notes 159, 164, 173, 193 infra.

156. "[M]ore must be shown in support of a complaint thereunder [\$ $404(\mathrm{a})]$ than to point to desired improvements in service that might confer substantial benefits and to show a plausible manner in which their advent might be effected. . ." 1 Av. L. REP. II 22205 , at 14201 .

157. No. 7382, CAB, Sept. 23, 1958, passin.

158. Fort Worth contended that the loss of Fort Worth passengers to Dallas seriously prejudiced the economy of Fort Worth, and that local facilities catering to travelers and visitors were losing business, particularly the trade of those whose destination was Fort Worth, to Dallas. Brief of Fort Worth to the Board, pp. 25-28. The hearing examiner concluded that about $38 \%$ of "true" Fort Worth passengers enplane or deplane at the Dallas airport. No. 7382, CAB, Sept. 23, 1958, app. 13. The Board conceded that the evidence supported Fort Worth's contentions, but stated that service at the Dallas airport was "reasonably available" and "highly attractive, thereby according Fort Worth an important supplemental service." 1 Av. L. REP. $\{22205$, at 14198. Moreover, the Board noted that a substantial number of Dallas passengers use the Fort Worth Airport. No. 7382, $C A B$, Sept. 23, 1958, p. 4. This observation overlooks the fact that, because of the distance involved, see note 141 supra, few Dallas passengers deplaning at the Fort Worth airport would patronize Fort Worth travel facilities, while many deplaning Fort Worth passengers would use Dallas hotels and shops. 
bad service at Fort Worth would induce many potential air travelers to use surface transportation. ${ }^{159}$ In fact, the Board's reasoning would countenance a vicious downward spiral: poor service discouraging patronage, less patronage justifying curtailed operations, reduced operations lowering demand still further until the airlines are serving only those travelers to whom air transportation is indispensable. ${ }^{100}$ The Fort Worth test is, in sum, public necessity, not public convenience. ${ }^{161}$

The Fort Worth case also distorts section 404(a)'s explicit directive that "every air carrier" provide "adequate service." In most air markets, the Board's aggregate-service approach effectively relieves the airlines of individ-

159. "It . . . appears . . . that a substantial demand for air transportation existed in this area, and that the number of persons who actually presented themselves to applicant for transportation is no true index of the number of persons who might have presented themselves had the applicant not curtailed its operation so drastically." Airline Feeder System, Inc., Grandfather Certificate, 1 C.A.A. 167, 171 (1939). (Emphasis added.)

In the Washington-Baltimore Adequacy of Service Investigation, No. 8148, CAB, 1959, Baltimore has charged that its poor traffic development is the direct result of the poor volume of service supplied. Compare Israel, Television Editorial, The Opportunity at Friendship Airport, WJZ-TV, Baltimore, Md., Dec. 10, 1958 (Baltimore passengers use Washington Airport because of poor local service). The carriers, on the other hand, contend that Baltimore is receiving bad service because of inadequate demand. Whatever the reason, traffic is definitely decreasing. In the first half of 1958, airline departures in Baltimore amounted to 8,913 ; in the first half of $1957,9,218$. Brief of the Greater Baltimore Committee to the Board, p. 6, No. 8148, CAB, 1959.

160. The CAB has tacitly conceded that demand will increase as service is improved. In the ISeven States Area Investigation, 1A Av. L. REP. If 22226 (CAB Dec. S, 1958), the Board replaced a trunk carrier-Western Airlines-with a feeder line-Frontierbecause the Board felt that local service carriage was better adapted to the needs of the communities in question. In so doing, the $\mathrm{CAB}$ noted that more frequent flights and better-timed schedules would double the amount of trafic which had enplaned during Western's tenure. Western agreed. No. 7454, CAB, Dec. 8, 1958, p. 7 \& n.13.

Responding to the Questionnaire, one city pointed out that its air service was adequate primarily because the serving carrier was scheduling its flights to major destination points at opportune times. As a result, usage has been "splendid." Questionnalre. Obviously, if a carrier furnishes one flight a day at 3:00 A.M., it will accommodate the people willing to board at such an early hour. Still, this does not mean that service at more reasonable hours will not generate demand far in excess of present levels.

161. Compare 'Atchison, T. \& S.F. Ry. v. Public Serv. Comm'n, 130 Kan. 777, 783, $2 \& 8$ Pac. 755, 759 (1930) (necessity does not mean something indispensable or something that is absolutely essential, but rather a public need, without which the public-the people generally of the community-would be inconvenienced or handicapped to their detriment in pursuance of business or wholesome pleasure as compared with that engaged in by others generally, similarly located).

One eastern airport manager, claiming his city to be the second fastest growing community in the United States, stated that trunkline service had been steadily decreasing because the carriers found it more convenient to force the area's air travelers to utilize service at a larger, neighboring community. "[I]t's for the convenience of the carriers that our service is inadequate. This is the national trend." QUESTTONNAIRE. 
ual responsibility for inadequate operations. ${ }^{162}$ Only the single-carrier community lacking access to any airport but its own is unaffected by Fort Worth; its burden of proof in 404(a) proceedings remains limited to demonstrating the serving airline's inadequacies. But any city located near another community's airport must prove both local and adjacent operations inadequate, even if both involve the same carrier. And a multi-carrier community-served through local and/or neighboring airports-must demonstrate cumulatively deficient service in order to sustain section 404(a) charges. Inadequacy is thus geared to aggregate service, and the community has a heavy burden of proof. ${ }^{163}$ Were this burden met, the Board would face as yet unsolved problems in framing a remedial compliance order which would both apportion blame among the respondent carriers and effectuate adequate service. ${ }^{104}$ Finally, Fort $W$ orth may operate in the future to harm carrier-community relations, since a city which would attack the operations of some of its airlines must now subject them all to $\mathrm{CAB}$ investigation. ${ }^{\mathbf{1 6 5}}$

Fort Worth further reduces the airlines' section 404 (a) obligations by relieving an authorized competitor of the duty to exploit its certificate grant aggressively. ${ }^{166}$ Here, the Board's premise-that the latent rival constitutes a

162. "While such Braniff service would be plainly inadequate in this market if it were the only carrier serving the market, nevertheless the efforts of Braniff and the response thereto of Fort Worth travellers demonstrate that Braniff's service is adequate to meet the needs of the public in view of the additional services operated by American." 1 Av. L. Rep. $\llbracket 22205$, at 14199-200.

The act speaks of aggregate service only in terms of providing "through service ... in connection with other air carriers." Section 404(a) of the act.

163. Since carriers have great freedom in changing schedules, Board consideration of the operating levels of all carriers is illusory. Flights might be increased until a Board determination of adequacy is made, and then decreased, forcing the community once again to undertake the arduous prosecution of a $\S 404$ (a) charge. Cf. Eastern Airlines, Inc.Memphis-Greenville Operation, 4 C.A.B. 429, 431. (1943) (schedules in operation at any one time not criteria of adequate service since subject to change).

164. See Fort Worth Investigation, No. 7382, CAB, Sept. 23, 1958, p. 10 n.11 ; Washington-Baltimore Adequacy of Serv. Investigation, No. 8148, CAB, 1959. Baltimore is contesting the fact that, even though the initial decision of the hearing examiner fully accepted the overall inadequacy of Baltimore's air service, the air transportation in individual Baltimore markets was found to be adequate. "Can the whole partake of a different quality than the parts? We think not, and we submit that the Board should reject the ultimate defeatism of the Initial Decision and should approach seriously the taskadmittedly not simple - of devising an effective remedy." Brief on Behalf of the Greater Baltimore Committee to the Board, p. 28.

165. Of course, those carriers not serving the markets at issue would not be involved.

166. One commentator has recently noted that, after competitive service has been authorized, the Board typically exercises no formal enforcement action with respect to how vigorously the new carrier competes, how effective its service is, or indeed, whether it inaugurates service at all. Richmond, Creating Competition Among Airlines, $24 \mathrm{~J}$. ArR L. \& Conr. 435, 436-37 (1957).

Replies to the Questionnaire demonstrate a correlation between effective competition and adequate service. Of the twenty-four cities deeming air service adequate, only two state that competition should be increased; of the forty-four denominating existent opera- 
threat to established carriers-is fallacious. As the Toledo case pointedly demonstrates, a carrier's indolence on short hops usually stems from its pursuit of long-haul, major-market traffic. ${ }^{167}$ Since an incentive to serve the smaller community is therefore lacking, established carriers would scarcely regard the threat of re-entry as endangering their market position. Moreover, as Toledo also illustrates, a decrease in alternative service available to the public enables serving airlines to reduce the quality and number of their flights. The number of passengers flown may remain unchanged, but they are not served as well. ${ }^{108}$ Latent competition, then, whatever its efficacy in other areas, is clearly an inappropriate doctrine in the context of air transportation. 109

As regards discrimination, the Fort Worth (and Greensboro) gloss on section 404 (b) - to the effect that disproportional service is irrelevant when geographically related communities have different economic structures-in effect expunges that section from the act. Though invariably engaged in business rivalry, neighboring cities are economically identical only by coincidence. Consequently, an unjustified disparity in air service irrationally upsets the competitive balance between nearby cities attempting to attract new industries, exploit existing resources, and develop tourist and convention trade. The

tions inadequate, twenty-one assert that more effective competition is needed. E.g.: "[I]ncrease in competition would improve service and promote business." "One main factor contributing to inadequate service is the absence of competitive service between trunklines now serving. ..." QUESTTONNAIRE.

167. While Capital was curtailing its service to Toledo, see notes 131-32 supra, it increased its systemwide operation $100 \%$ in the period 1955-58. Most of the increase was in the New York-Chicago and Washington-Chicago markets. See Exhibits of the City of Toledo, Toledo Adequacy of Service Investigation, No. 8851, CAB, 1959, Exhibit No. 17.

One of the collateral effects of the equipment and scheduling demands of carrier competition in major-market areas has been the reduction of service to intermediate points. GILL \& B B BtES 126-31.

168. See note 133 supra.

169. GILL \& BATES 15 (effective competition exists only if carriers influence services offered to or rates charged the air traveler). See United Air Lines Transp. Corp.Acquisition of Western Air Express Corp., 1 C.A.A. 739, 747 (1940) (intensity of competition not to be confused with the mere existence of a competitive situation); Fort Worth Investigation, No. 7382, CAB, Sept. 23, 1958, p. 1 (unused authorization furnishes no economic strength) (concurring and dissenting opinion); Boston-New York-AtlantaNew Orleans Case, 9 C.A.B. 38, 49 (1948) (evidence proves that development of traffic potential improves under the impact of competition). Compare Great Lakes-Southeast Serv. Case, 1A Av. L. Rep. $\llbracket$ 22211, at 14225 (CAB Sept. 30, 1958) (monopoly and twocarrier communities are usually underscheduled because of lack of effective competition). In this case, the Board also noted that authorizing an effective competitor would have a long-range impact on adequacy, but that the mere threat of competition would at best improve service temporarily. No. 2396, CAB, Sept. 30, 1958, p. 17.

Numerous Questionnaire statements also indicate the effect of decreased competition. E.g.: "Due to the lack of effective competition, the service by certificated air carriers has lagged far behind the improvement in service out of [a nearby city] . . . where there is effective competition." "[C]ompetition is nil and service reflects this. . .." 
CAB's decisions nevertheless permit airlines to discriminate against a city so as to jeopardize its relative market position. ${ }^{170}$ Worse, if two economically equivalent cities are in close geographical proximity, the CAB's construction of the section 404 (a) -404 (b) relationship can prevent the disfavored city from remedying unsatisfactory service. Under the Fort Worth rationale, when serving carriers provide disproportionately augmented service to one of two neighboring communities, the other community's service is enhanced rather than diminished by operations at the favored airport. ${ }^{171}$ Hence, the Board would allow airline partiality to injure a given city's enterprises catering to the traveling public, and to force a locality's traffic into using a distant airport. ${ }^{172}$

\section{The CAB and Community Development: A Proposal}

In viewing "adequate service" from the standpoint of a community's minimum needs rather than an individual carrier's statutory responsibilities, the $\mathrm{CAB}$ has ignored explicit language in the Civil Aeronautics Act and preferred the airlines' interests over those of the public. ${ }^{173}$ Of course, every city is not

170. Furthermore, if the Board adheres to its earlier announced policy requiring a community to proceed under $\$ 404(\mathrm{~b})$ rather than under $\$ 401(\mathrm{~h})$, an aggrieved city may be barred from seeking the services of an additional carrier to alleviate the injurious effects of discrimination. See Boston-New York-Atlanta-New Orleans Case, 9 C.A.B. 38,47 (1948).

171. Disagreeing with this rationale, thirteen cities report that their serving carriers are subjecting them to unjustified discrimination. Of these, twelve state that their service is inadequate. QuEsTronNaIRE.

If the Board's aggregate-service rationale is carried to its logical conclusion, a city alleging carrier discrimination must demonstrate that the total air service from the complainant city to a particular market is unduly out of balance when compared with the total air service of the neighboring community to the same market.

172. United Air Lines Transp. Corp., 1 C.A.A. 778, 789 (1940) ("A city receiving a minimum of air service cannot be expected to develop a large volume of long-haul traffic when there are, within a short distance, other cities having a greater frequency of schedules."); see American Airlines, Inc., 2 C.A.B. 436, 442 (1941); Eastern Airlines, Inc., 2 C.A.B. 676,680 (1941).

The Board may have presaged its Fort Worth and Greensboro holdings by dictum in the Philadelphia-Transatlantic Serv. Case, Av. L. REP. (1951-54 CAB Cas.) $\Uparrow$ 21454, at 16393 (1952): "[A] conclusion that any prejudice which might exist against Philadelphia is undue or unreasonable would subject the Board to a flood of complaints from municipalities that do not receive as much service as other communities of comparable size regardless of the need for service to such points." See also Reopened Charleston-Columbus Case, 1A Av. L. REP. If 22153, at 14063 (CAB Jan. 16, 1958).

173. Speaking of the certification process in general, a former chairman of the CAB said: "I feel that there has been an undue shift of emphasis from public conventience and necessity to the seeking and protection of private carrier rights." Rizley, Some Personal Reflections After Eight Months as Chairman of the Civil Aeronattics Board, 22 J. AIR L. \& Com. 445,450 (1955). One airport official, noting the .CAB's dissimilar treatment of carrier applications and community petitions, states: "The CAB will quickly do what it can if a carrier asks for something, but will side-step the issues when communities ask for something." QuestionNaIRE. But see United Air Lines, Inc. v. CAB, 19S F.2d 
necessarily entitled to all the air service it deems desirable. Still, a community which is able to generate demand and support additional operations should also be able to secure flights commensurate with its traffic potential. The same public convenience and necessity which warrant the authorization of first-carrier or competitive service also dictate that a certificated airline maintain substantial operations. ${ }^{174}$ Having reaped the advantages of controlled competition and government subsidy, ${ }^{175}$ the trunklines should serve all communities, not just large commercial areas. ${ }^{176}$ True, the swift development of an air network linking the nation's population centers is a desirable goal; but the attainment of this goal ought not and need not render other areas of the country aerially inaccessible. The $\mathrm{CAB}$ should therefore require the trunklines to devote more attention to traffic outside the long-haul market until feeder lines can provide a comprehensive pattern of air transportation for smaller communities. ${ }^{177} \mathrm{At}$

100, 107 (7th Cir. 1952) (public rather than carrier interest should contro1); Middle Atlantic Area Case (Pittsburgh), 10 C.A.B. 257, 266 (1949) (similar).

In the Washington-Baltimore Adequacy of Serv. Investigation, No. 8148, CAB, 1959, the hearing examiner excused the performance of Capital Airlines on the ground that the company had operational and financial problems. Taking exception to this, Baltimore asserts: "[W]e know of no theory whereby the obligation of a common carrier, whether common-law or statutory, can be disregarded because of internal problems of a company, fancied or actual." Brief of the Greater Baltimore Committee to the Board, p. 17.

174. [A] service is not necessarily adequate because the community . . . can conduct its business without further or additional service. To be adequate, they must safeguard the people generally from appreciable inconvenience in the pursuit of their business. ... [I]f a new or enlarged service will enhance the public welfare, increase its opportunities, or stimulate its economic, social, intellectual or spiritual life to the extent that the patronage received will justify the expense of rendering it, the old service is not adequate.

Muicahy v. Public Serv. Comm., 117 P.2d 298, 301 (Utah 1941).

175. Commercial aviation in the United States owes its origin, growth, development, and present structure to planning and financing by the federal government. REPORT ON AIrLInes 8. See Smith, Government Policy Concerning Airline Subsidy, 25 J. AIR L. \& Corr. 79 (1958).

176. Service to Springfield, Mass., 11 C.A.B. 747, 749 (1950) (interest to be served is national, not that of any particular area or community); Hector, Problems in Economic Regulation of Civil Aviation in the United States, 26 J. AIR L. \& Com. 101, 105 (1959) ("There are certain duties ... which the government must always enforce under the statute. First, the carriers must give adequate service to all communities to which they are certificated.") (Hector is a Member of the CAB and was a dissenter in the Fort Worth case).

177. See Seven States Area Investigation, 1A Av. L. REP. \ 22226, at 14304 (CAB Dec. S, 1958) ; Netterville, Local Service Airlines: Trunkline Suspensions in Aid of the Local Service Experiment, 26 So. CaL. L. Rev. 229 (1953). A large midwestern city reports: "Several years ago, American Airlines gave up hedge-hop service between Detroit and several cities to a local service carrier and with the increased service by the local service carrier, it has proved beneficial to all concerned." QuESTIONNAIRE. Another city asserts that the growth of local-service carriers has helped to offset poor air service resulting from its small population. Ibid. Immediate large-scale abandonment of the smaller cities to the local-service carriers is not advisable, however. Such abandonment 
the same time, the feeders should not be allowed to operate as small-scale trunklines in derogation of their certificate obligations. ${ }^{178}$ In this way, both trunk and feeder lines can be made to provide service realistically geared to the needs of cities which are not major centers of commerce.

To implement these objectives, the $\mathrm{CAB}$ should replace the Fort Worth concept of "adequate service" with one requiring every air carrier to participate actively in the promotion of local air travel. ${ }^{179}$ Thus, an airline holding a monopoly on a community's air carriage would be required to maintain operations sufficient not only to accommodate existing traffic but to develop latent demand as well. ${ }^{\mathbf{1 8 0}}$ And, when more than one airline serves a city, each carrier would have to provide enough service so that the competitive thrust of its presence could be felt. ${ }^{181}$ Token or nonexistent operations would be

would necessitate a large increase in subsidy, as these carriers are not yet self-sufficient. See note 71 supra.

178. See Adams, Future of the Local Service Carriers-Public Service vs. Federal Subsidy, 23 J. ArR L. \& Coxs. 127, 138 (1956); note 73 supra and accompanying text. In serving some communities, local-service airlines may encounter competition from the nonscheduled carriers. These carriers generally attract the most profitable traffic-military personnel, tourist business and the like-so that the feeders find it harder to serve a given area profitably. See note 73 supra. Accordingly, the CAB should maintain its present rigid restrictions on the number of flights flown by irregular and supplemental carriers. See generally Large Irregular Air Carrier Investigation, 1A Av. L. REP. $\{22247$ (CAB Jan. 28, 1959).

179. "Adequate service is a relative expression which has been construed to mean only that such facilities must be supplied as might be fairly demanded. . . This service is but the minimum standard fixed by the Act but the considerations of national policy require much more." Transcontinental \& W. Air, Inc., Additional North-South Calif. Serv., 4 C.A.B. 373, 375 (1943) (dictum). See also Southwest-Northeast Serv. Case, Av. L. REP. (1954-57 CAB Cas.) II 21892, at 14493 (1955). For a vivid discussion of the results obtained from "promotional" scheduling, see Cook, North Central Mass-Schedules Traffic, Aviation Week, Feb. 16, 1959, p. 38.

180. Compare Northwest Airlines, Inc., Mail Rates, 1 C.A.A. 275, 284 (1939) (singlecarrier adequacy subsumes frequent departures and sufficient capacity to meet the convenience of commerce). Frequent departures would prevent a monopolist from exploiting his position and restricting flights in order to increase his per-trip load factor.

181. Now that air transportation has progressed to an established industry status, where domestic certificated carriers for the most part no longer need subsidy support, and where continued growth of the industry is predicted on all sides, it is incumbent upon the Board to take the steps necessary to assure that all elements of the certificated industry are placed in a position to offer viable competition to their rivals.

REPORT ON AIRLINES 113. "[T]he Board should be directed to consider, in its determination of the public interest, convenience and necessity, competition to the extent practicable' rather than the present test, 'to the extent necessary.'" Id. at 267. For a discussion of the need for competitive service even when established carriers are maintaining adequate operations, see THomas 89 .

Once the airlines are compelled to compete, economic self-interest will force them to furnish a varied pattern of flights, which should in turn promote increased passenger traffic. See GILL \& Bates 624-28; Hector, supra note 176, at 105 . If a carrier does not 
precluded, but a competing carrier would not have to maintain the same level of operations as would one enjoying a local monopoly. ${ }^{182}$ Holding every nonmonopoly carrier to standards of actual competition would enable complainants to institute proceedings against laggard carriers only, would make it easier for a community to demonstrate insufficient service, and would facilitate the formulation of $\mathrm{CAB}$ remedies. Most important, the downward spiral of air service permitted by the Fort Worth doctrine of adequacy would be reversed through effective competition. ${ }^{183}$ On the other hand, no carrier should be compelled to promote increased air travel in the face of a community's proved unresponsiveness. ${ }^{184}$ If an airline's attempts to develop new traffic are frustrated by the public's apathy, the airline may be justified in curtailing operations. A reduction in air transportation cannot be avoided if a community fails to support sufficiently adequate service to activate latent passenger demand.

Abandonment of the cumulative-service doctrine alone will not link "adequate service" to community potential; the $\mathrm{CAB}$ must also cease viewing neighboring airports as an aggregate. ${ }^{185}$ Unlike a satellite community such as Pasadena, California, a city which forms the nucleus of an independent traffic-generating area-Fort Worth or Baltimore, for example-is not receiving adequate service if its traffic is forced to patronize a nonlocal airport. ${ }^{186}$ Indeed, when passing on applications for certificates, the CAB recognizes that

in fact compete after being authorized to do so, it is either disregarding its certificate obligations, unable to fulfill them, or in a market unable to support competitive service. Fort Worth Investigation, No. 7382, CAB, Sept. 23, 1958, p. 2 (concurring and dissenting opinion). When lack of competition in a particular market is a product of a carrier's deliberate neglect, either a compliance order should issue or its grant of authority should be withdrawn and another carrier substituted. See ibid. But see Ryan, The Revocation of an Airline Certificate of Public Contenience and Necessity, 15 J. AIR L. \& Com. 377, 388 (1948) (CAB has power to revoke a certificate only upon finding a "wilful" violation of the act, although "suspension" is permissible) ; Note, 16 J. AIR L. \& CoMr. 471, 475-82 (1949) (similar). If a failure to compete stems from an individual infirmity, withdrawal and substitution seem to constitute the only feasible remedy. See Denver Service Case, Av. L. REP. (1954-57 CAB Cas.) I 21877, at 14439 (Nov. 14, 1955) ; New York-Florida Case, Av. L. Rep. (1954-57 CAB Cas.) If 21993, at 14764, 14787 (1956). And, if traffic clearly cannot support competitive service, the superfluous carrier should be directed to surrender its certificate. "In a general sense, competition is unusually beneficial, but it is better to have one airline making money than two starving." QuestionnaIRE.

182. Cf. Great Lakes-Southeast Serv. Case, No. 2396, CAB, Sept. 30, 1958, p. 4 (concurring and dissenting opinion).

183. See Colonial Airlines, Inc., 4 C.A.B. 552, 555 (1944).

184. See text accompanying notes 196-98 infra.

185. See Fort Worth Investigation, No. 7382, CAB, Sept. 23, 1958, p. 2 (concurring and dissenting opinion) ("Since Braniff's certificate calls for service at Fort Worth, and as long as the Act requires adequate service by each carrier, Braniff's obligations at Fort Worth cannot be satisfied by its service at another city or by the service of another carrier:").

186. In 1956, the gross ticket sales at New Haven for all carriers were more than $\$ 2,600,000$, but because of the infrequency of local flights, at the local airport, only $4 \%$ of the tickets sold were for flights originating at New Haven. Brief of Bridgeport, New 
it should ignore the demand potential of an independently-served community in defining the traffic radius of an adjacent city. ${ }^{187}$ Similarly, air transportation at a neighboring community should not be deemed a substitute for local operations in an "adequate service" proceeding, unless economic unity rather than geographic proximity justifies a carrier's attempt to serve two cities through the same airport. Once the $\mathrm{CAB}$ has decided in certification proceedings that the public convenience and necessity warrant authorized air service at each of several local airfields, the same criteria should preclude carrier discrimination which results in a regional airport. ${ }^{188}$

In addition, the Board should ensure that competition between geographically proximate centers is not irrationally affected by the airlines' scheduling policies. Competition should be defined functionally-in terms of whether communities are seeking the same trade-and not arbitrarily, as under the $\mathrm{CAB}$ test requiring substantially similar economic structures. If two cities are in fact commercial rivals, differences in actual community need should be examined to determine whether the service provided either is economically disproportionate. Generally, the $\mathrm{CAB}$ should not find that carrier benefits deriving from discriminatory practices justify discrimination. ${ }^{189}$ Finally, since discrimination

Haven, and New London, p. 15, Northeastern States Area Investigation, No. 6436, CAB, 1959.

Baltimore, in the Washington-Baltimore Adequacy of Serv. Investigation, No. 8148, $\mathrm{OAB}, 1959$, has charged that it has received only token air service, primarily because of its proximity to Washington. Brief of the Greater Baltimore Committee to the Board, p. 5. Eleven cities assert that the proximity of another airport is prejudicial to local efforts to obtain adequate service; the neighboring airfields are an average of thirty-five miles away. QuestionNaIRE. One city, totally dependent upon air service at a neighboring community's airport and unable to obtain inaugural air service, is further inconvenienced by the fact that limousine service to the neighboring airport is unavailable and the taxi fare is unreasonably expensive. QUestionnaIRE.

See generally United Air Lines Transp. Corp., 1 C.A.A. 778, 789 (1940); American Airlines, Inc., 2 C.A.B. 436, 442 (1941); Eastern Airlines, Inc., 2 C:A.B. 676, 679-80 (1941).

187. Reopened Charleston-Columbus Case, 1A Av. L. REP. I 22153, at 14062 (CAB Jan. 16, 1958) (Greensboro not allowed to include neighboring Winston-Salem within its traffic-generating area when attempting to demonstrate the need for additional service, as Winston-Salem is the "core" of its own traffic-generating area and is entitled to adequate service at its own airport).

188. See Trans-Texas Renewal Case, No. 6485, CAB, Nov. 1, 1955, pp. 11-12 ("The Examiner found, and we agree, that the service to be provided to Dallas and to Fort Worth should be provided through separate airports. Fort Worth is fast becoming a center of attraction for all types of business . . . which emphasizes the need for air service to Fort Worth.").

189. See Hawaiian Common Fares Case, 10 C.A.B. 921 (1949) (refusal to allow decrease in rates which would have prejudiced competing cities to their economic detriment). Cf. ICC v. Chicago, R.I. \& P. Ry., 218 U.S. 88, 102 (1910) ("The [Interstate Commerce] Commission was instituted to prevent discrimination between persons and places. It would indeed be an abuse of its powers to exercise them so as to cause either."). One city in the Pacific coast area states: "We believe ... we are discriminated 
and inadequate service often co-exist, a combined section 404(a)-404(b) complaint should compel the Board to investigate both charges. ${ }^{190}$

To facilitate the revision of CAB policy proposed above, the Board should adopt a revised certification procedure. Every carrier applying for a new (or an amended or extended) route should be required to submit a service plan detailing the quality and approximate schedules of the minimum number of flights which the carrier will maintain. ${ }^{121}$ The scheduled communities should then be requested to suggest amendments to the service plan-amendments which, after a hearing, the $\mathrm{CAB}$ could accept or reject. If the route certificate is granted, the carrier should be required to inaugurate the service plan as approved by the $\mathrm{CAB}$; and failure to do so should evoke a $\mathrm{CAB}$ compliance order issued upon a community's complaint. ${ }^{192}$ Deviations from the service

against in the attraction of tourist business by reason of the fact that carriers serving the California market have instituted tourist excursion fares substantially lower than regular tourist or coach fares.... We have not been able to have this situation remedied through negotiations with the carriers and may have to resort to a formal complaint to the Civil Aeronautics Board." Questronnaire.

190. For cases under the Interstate Commerce Act, see Ayrshire Collieries Corp. v. United States, 335 U.S. 573, 592-93 (1949) (discrimination not justified by promotion of carrier interests) ; Union Pac. R.R. v. United States, 313 U.S. 450, 467 (1941) (same); United States v. Illinois Cent. R.R., 263 U.S. 515, 524 (1924) (preference based on honest carrier intentions may nevertheless inflict undue prejudice; self-interest of carriers may not override the requirement of equality). For other cases under the Interstate Commerce Act, see United States v. Baltimore \& O.R.R., 333 U.S. 169 (1948) (forbidding railroad from forcing shipper to take delivery at point on line less convenient than its front door); Transfer of Passengers Through New York and Newark, 165 I.C.C. 497 (1930) (disapproval of rates and services which discriminated against one borough of New York City in favor of another).

191. See Fort Worth Investigation, 1A Av. L. ReP. f 22205 (CAB Sept. 23, 1958). Protection of the public from unjust discrimination and mistreatment by air carriers and their agents is one of the main economic objectives of the act. 1955 CAB ANN. REP. 11.

192. In the congressional hearings leading to the passage of the act, a former Director of the Bureau of Air Commerce stated that, in order for a carrier to acquire a certificate, the carrier should submit a schedule showing the number of flights proposed and the time involved. See Rhyne, The Civil Aeronautics Act Annotated 101 (1939). Current CAB Regulations do not require such exhibits. See 14 C.F.R. \& 201.4 (1956). On the other hand, in past certification proceedings carriers have usually been required to present a service operation plan, but only as evidence of their being "fit, willing and able." See American Export Lines, Inc., 3 C.A.B. 294, 298 (1941); Delta Air Corp., 2 C.A.B. 447, 487-88 (1941); Trans-Southern Airlines, Inc., 2 C.A.B. 250, 254 (1940); THomas 67 . The Board has pointed out that, under ordinary circumstances, less than a minimum of two daily round trips serving all points on a route does not constitute service adequate to meet the needs of commerce and the postal service. Texas-Oklahoma Case, 7 C.A.B. 481,529 (1946).

Under current FCC Regulations, a licensed radio operator is required to maintain a minimum operating schedule of two-thirds of the total hours it is authorized to broadcast between 6 A.M. and 6 P.M. FCC Radio Regs., 47 C.F.R. $\$ 3.71$. (1958). See M. B. Scott, 2 F.C.C. 158 (1935) (radio license not renewed for failure to comply with minimum operating requirements). Television broadcasters are under a similar, though less stringent, obligation. FCC Radio Regs., 47 C.F.R. § 3.651 (1958). 
plan without community approval should be illegal unless preceded by $C A B$ investigation and consent. ${ }^{193}$ Alternatively, in an appropriate case the CAB might approve a service plan for only a limited time. Absent the plan's renewal on a showing that operations justified its retention, carriers could reduce service unilaterally following the temporary period.

Utilization of the suggested service plan would not be inconsistent with the carrier's statutory freedom to "add to or change schedules, equipment, accommodations, and facilities ... as the development of the business and the demands of the public shall require."194 At present, a carrier may not revise its operations in a manner producing an inadequate level of service. The service-plan approach would simply define adequacy during certification proceedings rather than during a retroactive investigation under section $404(a) .{ }^{105}$ The controlling determinant-community need-would remain unaltered. Predesignating a standard of adequacy seems preferable to current procedures which, pending the extended processing of a community's complaint, afford no interim remedy for inadequate service. ${ }^{196}$ Furthermore, once a service plan

193. In the Washington-Baltimore Adequacy of Serv. Investigation, No. S14S, $\mathrm{CAB}, 1959$, Baltimore has suggested that, if the $\mathrm{CAB}$ finds that carriers are rendering inadequate service, the Board should issue an order outlining the type of service that should be provided. Carriers should then be given 30 to 60 days to furnish schedules by which they propose to effectuate the Board's order, Baltimore reserving the right to take exception and suggest improvements. Once the Board deems the schedules to be in substantial compliance with their earlier order, the proposed flights are to be inaugurated within 30 days. Brief of the Greater Baltimore Committee to the Board, p. 35.

194. To speed investigation of a carrier petition to alter its service plan, so as to avoid undue hardship when maintaining the minimum level of service proves difficult, such a petition might be given priority on the $\mathrm{CAB}$ docket. Alternatively priority could be granted only to subsidized carriers. See $\S 405$ (e) of the act (now $\$ 405(b)$ ), providing for preferential docketing of carrier opposition to the mail schedules ordered by the Postmaster General.

For a discussion of the procedure for obtaining the ICC approval necessary to change or discontinue rail operations under the Transportation Act of 1958, see Freas, Some Aspects of Transportation Regulation, 26 I.C.C. PRAC. J. 6 (1958). See also Conant, Railroad Service Discontinuances, 43 MINN. L. Rev. 275 (1958); Weissman, Railroad Abandonments: The Competitive Ideal, id. at 251 (1958).

195. Section $401^{\prime}(\mathrm{f})$ of the act (now $\S 401(\mathrm{e})$ ). Existing law is not clear on the scope of the CAB's power to limit or restrict certificates with respect to schedules, equipment, accommodations or facilities. See 1957 CAB ANN. REp. 31. In the Large Irregular Air Carrier Investigation, No. 5132, CAB, Jan. 28, 1959, pp. 8-12, the Board said by way of dictum that $\S 401(\mathrm{f})$ limits the Board's power to "restrict the performance" of authorized transportation. Nevertheless, the Board deemed itself empowered to specify services to be rendered, for if it could not reasonably define in a certificate the scope of required operations, it could not grant certificate authority efficiently.

Under the service-plan approach, carriers would remain at liberty to expand operations and juggle arrival and departure hours as the needs of the community and the carrier demand, so long as the minimum number of flights of predetermined quality-first class, coach, non-stop-is maintained, and flights are not scheduled at unreasonable hours.

196. The Board has previously granted certificates to local-service carriers on the condition that they stop at each point authorized on every flight to "insure adequate local 
were approved, subsequent $\mathrm{CAB}$ investigation would rarely be necessary except when a carrier failed to increase its operations correlatively with a growth in traffic demand. ${ }^{197}$

An invaluable complement to the service-plan proposal would be the general issuance of "use it or lose it" certificates. ${ }^{198}$ Were these certificates the usual concomitants of an approved service plan, a community which failed to generate a predesignated level of traffic over a specified period of time would suffer a reduction in the amount of service which it could command from each carrier. In fact, the cancellation of all air service of one or more carriers might then be warranted. Hence, a carrier would not be locked into a perpetually unprofitable service-plan obligation, and the burden of supporting increased operations would rest on the community which petitioned for them. ${ }^{199}$ The resulting mutual responsibility of carrier and community would undoubtedly encourage them to cooperate with one another..$^{200}$

\section{CONCLUSION}

Ultimate resolution of the airline-service problems confronting smaller communities depends upon a choice between two competing philosophies: one, that government control should be limited to the regulation of competition, safety,

service to all certificated points, ... to permit the carrier the utmost flexibility of operations consistent with the above, and ... to provide the public with the fastest, most direct, and most frequent service consistent with the above." Middle Atlantic Area Case, 10 C.A.B. 41, 45 (1949). See also North Central Case, 7 C.A.B. 639, 680 (1946) (certification granted on the "express assumption" that fully adequate service-at least two round-trip schedules daily-be provided to each certificated point).

197. The average time between the filing of a first petition and the Board's final opinion is $\mathbf{5 2 5}$ days; and a proceeding of large scope may take 1004. Westwood, Proccdure in New Route Cases before the Civil Acronautics Board, 14 J. AIR. L. \& Com. 267, 270-71 (1947).

On January 1, 1955, the Board was faced with 558 cases in various stages of proceeding, and 557 cases still to be heard, some of which dated back to 1945. Rizley, Some Personal Reflections After Eight Months as Chairman of the Civil Aeronautics Board, 22 J. AIR L. \& CoMr. 445, 448 (1955).

198. The side effects of the service-plan proposed would be: only those carriers that actually intend to provide more than token service to a community would apply for authorization; the Board would analyze community need carefully, for, if the minimum service to be provided is not self-supporting, subsidy payments may be needed to underwrite operations; the Board would also have to consider the impact of competition from nonscheduled carriers on the required operations of certificated airlines, and thus would have to evaluate an industry factor largely independent of $\mathrm{CAB}$ regulation.

199. See Seven States Area Investigation, 1A Av. L. REP. If 22226 (CAB Dec. 8, 1958), discussed notes 116-19 supra and accompanying text.

200. "Too often, a smaller community which has finally gained a place on the air map of the United States, begins to take this challenge too much for granted and after finds itself faced with early loss of its new gotten gain." Address of Perry H. Taft, National Airports Conference, Nov. 3, 1957. For suggestions as to what state and municipal officials can do to encourage air travel, see Adams, Future Local Airline Service Depends on State Support, 20 J. AIR L. \& CoMr. 403, 412-14 (1953). 
rates, and subsidy, and that the airlines should be free to serve the national air market in a manner maximizing their profits ; ${ }^{201}$ the other, that the industry has assumed the role of a quasi-public utility, and that the service it renders is therefore subject to regulation. ${ }^{202}$ The question, then, is whether the public interest is better served by allowing the airlines to continue their singleminded pursuit of large-market traffic, or by requiring them to promote less lucrative (if not unprofitable) operations in other areas. ${ }^{203}$ The choice is not an easy one, for any losses incurred in local operations must be absorbed by both the general public-through subsidy payments-and the flying publicthrough increased rates. ${ }^{204}$ At present, though, it would seem that the needs of the smaller community are being unduly sacrificed in an effort to keep rates and subsidy at a minimum, and that the national economy will benefit, in the long run, from a more tightly-knit pattern of air operations. ${ }^{205}$

201. "The community must join the airline as a partner in the promotion of the use of the airline by its citizens. This partnership must, however, be two way. The community must periodically meet with the airline's officials to determine whether or not the airline is truly exploiting the full air transportation potential of the community." Address of Perry H. Taft, supra note 200. Compare Seven States Area Investigation, $1 \mathrm{~A}$ Av. L. REP. If 22226, at 14320-21 (CAB Dec. 8, 1958) (management expected to search out and promptly remedy route and service deficiencies), with id., No. 7454, CA.B, Dec. 8, 1958, pp. 136-37 (cities responsible for ensuring that actual use of air service lives up to expectations, and that required traffic is developed).

202. See Hector, Problents in Economic Regulation of Civil Aviation in the United States, 26 J. Air L. \& Com. 101, 106 (1959).

203. See Thomas at iv.

204. Two commentators doubt whether the trunklines will in fact incur heavy losses by serving small towns. "The more logical conclusion is merely that these towns do not contribute as much to the profitable operation of the company as large towns." Maclay \& Burt, Entry of New Carriers Into Domestic Trunkline Air Transportation, $22 \mathrm{~J}$. AIR L. \& CoN. 131, 154 (1955).

205. See New York-Florida Case, No. 3051, CAB, Sept. 28, 1956, p. 5 n.7 ("[A] policy that encourages the deterioration of air service to the smaller cities . . . is completely contrary to the public interest."). See also Great Lakes-Southeast Serv. Case, No. 2396, CAB, Sept. 30, 1958, p. 10 ("We cannot fulfill our [CAB] responsibilities for developing a sound route structure if we subordinate that function to the preservation of revenues for the existing carriers."); Airline Feeder System, Inc., 1 C.A.A. 167, 171 (1939); Adams, Future of Local Service Carriers-Public Service vs. Federal Subsidy, 23 J. Arr L. \& Cosr. 127, 130 (1956).

In its May 1954 report to the President, the Air Coordinating Committee observed that high-speed, long-range, nonstop operations must not be accomplished at the cost, neglect, or substantial impairment of service to intermediate points. The Committee suggested the development of appropriate aircraft for short-haul operations; assigning trunklines responsibility in some instances for providing service to additional intermediate points, and requiring that they "meet their responsibility for maintaining adequate service to all certificated points"; and, in other situations, the development of self-sufficient area carriers. "It is . . . necessary for the industry and the CAB to judiciously evolve the best means of assuring adequate service to small terminal and metropolitan centers." Uis. President's Air Coordinating Comimittee, Civil Air Policy 12 (1954). 
APPENDIX

The Journal Questionnaire

1. How large is the population served by your airport? How large is the area in diameter? Is the area primarily industrial, marketing, agricultural, mining or institutional?

2. How satisfactory is surface transportation to and from your city?

3. What regularly scheduled commercial airlines are presently serving your city airport?

4. When was service first instituted?

5. Do you feel that your city is presently receiving adequate airline service commensurate with its needs? If not, in what respects is it inadequate?

6. Have any of the carriers certificated to serve your city failed to initiate service? If so, do they intend to initiate service in the near future?

7. Have any of the carriers certificated to serve your city recently decreased or abandoned service? If so, why?

8. How cooperative have the certificated carriers been in complying with requests for improved service?

9. Are facilities at your airport sufficient to meet potential demand for services (as opposed to present supply of service) ? Have you improvement plans underway? When will they be completed? How will they be financed?

10. What degree of competition exists between carriers serving your area? Do you believe it should be increased?

11. Do you feel that communities with whom you compete directly in the attraction of tourists, new industries, new firms, and the like, receive better air service? If so, is this discrimination justified? What steps have been taken to alleviate this condition?

12. How far is the nearest airport to your own? Do many of your residents use another airport? Why? Has the proximity of another airport prejudiced your city in its attempt to obtain more adequate air service?

13. In what Civil Aeronautics Board proceedings in the past has your city taken part? What was the extent of your participation? What was the outcome?

14. In any of these proceedings, have you favored one carrier over another? If so, for what reasons?

15. Has your city, in general, retained local or Washington counsel in proceedings before the $\mathrm{CAB}$ ?

16. Has your city ever retained the services of aviation consultants in presentation of argument before the $\mathrm{CAB}$ ?

17. To what extent have you enlisted the aid of your governor, senator or representatives? Department of Defense? Post Office? How have they participated?

18. Has your city ever considered filing a complaint against a carrier on the ground that you were receiving legally inadequate air service? Might you do so in the future?

\section{Responding Cities}

The Yale Law Journal received replies to the Questionnaire from the following seventy cities; they are listed in descending order of approximate population served by the local airport. 
Boston, Mass.

San Francisco, Cal.

Pittsburgh, $\mathrm{Pa}$.

Detroit, Mich.

Charlotte, N.C.

Baltimore, Md.

Seattle, Wash.

Tacoma, Wash.

Salt Lake City, Utah

Chattanooga, Tenn.

Des Moines, Iowa

Rochester, N.Y.

Scranton, $\mathrm{Pa}$.

Tampa, Fla.

Sacramento, Cal.

Huntington, W. Va.

Wilkes-Barre, $\mathrm{Pa}$.

Richmond, Va.

Norfolk, Va.

Allentown, $\mathrm{Pa}$.

Phoenix, Ariz.

Asheville, N.C.

Albany, N.Y.
Columbia, S.C.

Syracuse, N.Y.

Spokane, Wash.

Wheeling, W. Va.

Lexington, $\mathrm{Ky}$.

Baton Rouge, La.

Fresno, Cal.

St. Petersburg, Fla.

Wilmington, Del.

Harrisburg, Pa.

Cedar Rapids, Iowa

Raleigh and Durham, N.C.

Lancaster, $\mathrm{Pa}$.

Springfield, Mass.

Roanoke, Va.

Evansville, Ind.

Moline, Ill.

Madison, Wis.

Corpus Christi, Tex.

Sioux City, Iowa

Winston-Salem, N.C.

Portland, Me.

Colorado Springs, Colo.
Terre Haute, Ind.

New London, Conn.

Fargo, N.D.

Tallahassee, Fla.

Topeka, Kan.

Salem, Ore.

Ogden, Utah

Las Vegas, Nev.

Frankfort, $\mathbf{K y}$.

Cheyenne, Wyo.

Muskegon, Mich.

Billings, Mont.

Grand Junction, Colo.

Concord, N.H.

Bangor, $\mathrm{Me}$.

Fort Smith, Ark.

Casper, Wyo.

Tuscaloosa, Ala.

Dodge City, Kan.

Walla Walla, Wash.

Twin Falls, Idaho

Montpelier, Vt.

Jackson, Wyo. 